\title{
39. INFLUENCE OF CARBONATE DISSOLUTION, CLIMATE, SEA-LEVEL CHANGES AND VOLCANISM ON NEOGENE SEDIMENTS OFF NORTHWEST AFRICA (LEG 41)
}

\author{
Liselotte Diester-Haass, Geologisch Paläontologisches Institut der Universität Kiel, \\ Olshausenstr. 40/60, 23 Kiel, Federal Republic of Germany
}

\begin{abstract}
A coarse fraction analysis $(>40 \mu \mathrm{m})$ has been carried out on the Neogene sediments from Sites $366,367,368$, and 369 of Leg 41 , and the percentage composition of the coarse fractions is given.

Influence of calcium carbonate dissolution, shown by the degree of fragmentation of planktonic foraminifers and by plankton/benthos ratios of foraminifers, reveals parallel variations at Sites 366 and 369 , with a maximum of dissolution in the upper middle Miocene and a minimum in the Plio-Pleistocene sections.

Description of Neogene climatic variations is based on the amount of terrigenous material and desert quartz numbers in the frac.uons $>40 \mu \mathrm{m}$ of Site 369 . Early and middle Miocene climate in the Sahara at the latitude of Site 369 has been arid. From late Miocene to Pleistocene, climate has been similar to that during late Quaternary, with alternations of arid climate and more humid climate with greater rainfall and river supply.

Sea level was probably considerably lower than today during the early Miocene and perhaps during a short period of the late Miocene.

Volcanic glass and ash layers in Site 369 can be correlated with known phases of volcanic activity on the Canary Islands.
\end{abstract}

\section{INTRODUCTION}

The investigation of Neogene sediments of Leg 41, Holes 366 A (2860 m water depth), $367(4748 \mathrm{~m}), 368$ $(3367 \mathrm{~m})$, and $369(1760 \mathrm{~m})$ (Figure 1) is based on about 420 samples taken by $U$. Pflaumann (this volume).

The samples were dried, weighed, and wet sieved through $40 \mu \mathrm{m}$ and $63 \mu \mathrm{m}$ mesh. The $40-63 \mu \mathrm{m}$ and $>63$ $\mu \mathrm{m}$ fractions were dried and weighed. The $>63 \mu \mathrm{m}$ material was sieved into the following fractions: $63-125$, $125-250,250-500,500-1000 \mu \mathrm{m}$. The weight of each fraction was measured, and its percentage of the total sand fraction was calculated.

A component analysis has been carried out. In each fraction about 800 grains have been determined. The percentage of each grain type in each fraction and of the total sand fraction has been calculated.

The following grain types have been identified: benthic foraminifers (perforate, imperforate, and arenaceous), planktonic foraminifers (whole tests and fragments), sponges, molluscs (bivalves, gastropods and pteropods), ostracodes, echinoderms, fish debris, quartz grains (colorless and quartz grains with ironstaining), mica, other minerals (feldspar, dark minerals), dolomite, volcanic glass and ash, glauconite, relict components (black, corroded, bored shells from shallow water environment), phosphorite, clumps, pyrite.

Indications as to drilling disturbances were found in Core 369-1, where pteropods indicate probable mixing with sediments from the Holocene/Pleistocene boundary (see Pteropod section). There is also no correlation between the amount of terrigenous material and desert quartz numbers. In all other samples from Site 369 , however, this correlation is evident.

\section{GRAIN SIZE DISTRIBUTION}

The percent values of the $40-63$ and $>63 \mu \mathrm{m}$ fractions have been calculated from the weight of the total dry sediment and the weight of the fractions. In cases where clumps were present, they have been counted and their weight has been subtracted from the weight of the fraction. In the early Miocene sections from Site 368, pyrite is the dominant component. Here no grain size values are given.

In Site 369 sediments the percentage of the sand fraction of total sediment is less than $10 \%$, except for the uppermost two samples (>30\%). In Cores 369A-11, to $369 \mathrm{~A}-13$, sand fraction values are very low, about $1 \%$. The amount of $40-63 \mu \mathrm{m}$ fraction is generally lower, and variations are parallel to variations in the sand fraction percentages (Figure $2 b$ ).

At Site $366 \mathrm{~A}$, three sections can be distinguished (Figure 3b). In Cores 366A-1 to 366A-9, sand fraction percentages are high, about $20 \%-40 \%$, while the $40-63$ $\mu \mathrm{m}$ fraction percentages are about $5 \%$. In Cores $366 \mathrm{~A}$ 11 to $366 \mathrm{~A}-18$, sand fraction percentages are low, about $5 \%-10 \%$. The $40-63 \mu \mathrm{m}$ fractions form less than $5 \%$. In Cores $366 \mathrm{~A}-20$ to $366 \mathrm{~A}-27$, sand and $40-63 \mu \mathrm{m}$ fraction percentages increase again, up to $30 \%$ and $5 \%$, respectively.

At Site 368 (Figures 4b) the Plio-Pleistocene sediments have high sand fraction percentages. In the late Miocene they decrease and do not increase again in 


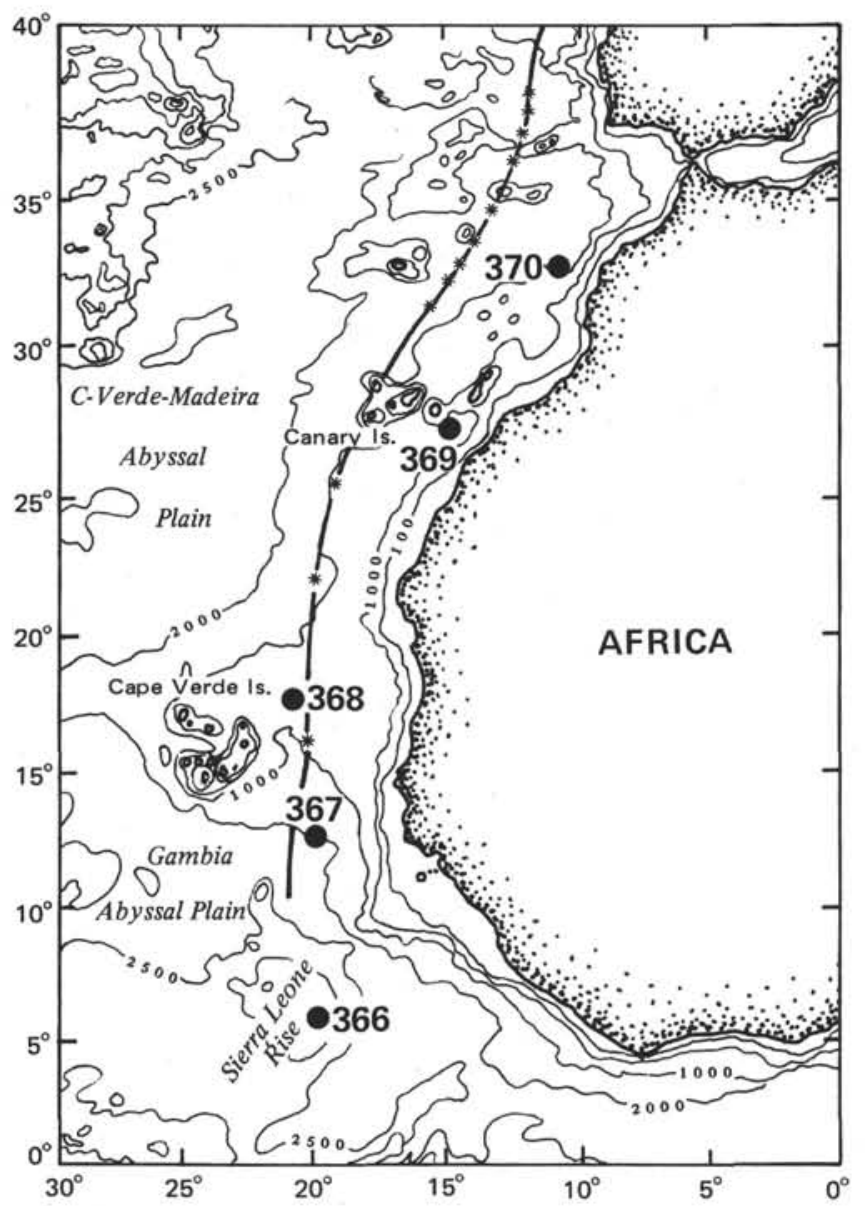

Figure 1. Location of sites.

the early Miocene. Grain sizes of Site 367 sediments are shown in Figure 5b.

Grain size distribution in the sand fraction shows the amount of the different sand sized fractions expressed as percent of the total sand $(>63 \mu \mathrm{m})$. In general there is a good correlation between amount of sand fraction and percent coarse fractions within the sand fraction. When there is much sand, the percentage of fractions $>125 \mu \mathrm{m}$ is high, but as sand percentages decrease the fraction 63-125 $\mu \mathrm{m}$ increases (Figure $2 \mathrm{c}$ to $5 \mathrm{c}$ ). The grain size distribution in Cores $366-24$ to $366-27$ is less precise because of large numbers of clumps and included foraminifers.

\section{COMPOSITION OF THE SAND FRACTION}

The main constituents of the sand fraction generally are planktonic foraminifers which make up $>90 \%$ of the sand fraction. Exceptions can be seen from the curves showing plankton/benthos ratios of foraminifers, radiolarian/planktonic foraminiferal ratios, terrigenous material, volcanic material, and pyrite. Where these constituents are abundant, percentages of planktonic foraminifers decrease.

Abundance of radiolarians is not shown in percent of the sand fraction, but as radiolarian/planktonic foraminiferal ratios. The percentage of radiolarians to the sum of radiolarians plus planktonic foraminifers, however, gives the approximate percentage of radiolarians in the sand fraction, except in those samples where components other than foraminifers form the major part of the sand fraction.

In Site 369 two intervals contain radiolarians (Figure 2d): Cores 369A-1 to 369A-6, with a maximum of $23 \%$ of radiolarians in the sand fraction, and Cores 369A-9 to $369 \mathrm{~A}-13$ (early Miocene), with up to $87 \%$ radiolarians in the sand fraction. In Site 366, radiolarians are only present in the lower Miocene section, Cores $366-16$ to $366-27$, with radiolarians making up to $13 \%$ of the sand fraction. One exceptional value of $40 \%$ occurs in Sample 366-25, CC (Figure 3d). At Site 368 a few radiolarians occur in the interval from Section 368-1-1 to Sample 2, CC, and comprise $1 \%$ of the sand fraction (Figure 4d). They are completely absent from Samples 368-2, CC to 368-12, CC. In Section 368-13-1 they reappear and form more than $50 \%$ of the sand fraction in Sections 368-14-3 to 368-152, and Sample 368-15, CC. Radiolarian/planktonic foraminiferal ratios are $>90 \%$ in Sections $368-14-3$ to 368-15-3. In Cores 368-17 to 368-19 pyrite is nearly the only constituent of the sand fraction. A few radiolarians occur but in insufficient amounts to give statistically meaningful percent values. At Site 367, only a few samples contain radiolarians. The abundances are $1.1 \%$ for Section $367-1-5,1.1 \%$ for Sample $367-2$, CC, and $4.2 \%$ in Sample 367-6, CC.

The presence of radiolarians in Cores 369A-1 to 369A-6 and Site 368 is exactly correlated to the presence of volcanic glass and tuff (Figures $2 \mathrm{k}, 4 \mathrm{k}$ ). The opal skeletons possibly are protected against dissolution due to $\mathrm{SiO}_{2}$ input from volcanic sources (Riedel, 1959). Detrital silicates deficient in $\mathrm{SiO}_{2}$ use $\mathrm{SiO}_{2}$ for silicate reconstitution reactions. When supply of $\mathrm{SiO}_{2}$ occurs only from biogenic particles, the particles are usually dissolved in normal fertile continental slope areas. However, where there is additional $\mathrm{SiO}_{2}$ supply from volcanic material, opal skeletons are at least partly protected against dissolution.

Diatoms are completely absent in fractions $>40 \mu \mathrm{m}$ of Sites 367 and 368. At Site 366 they occur only in the 40-63 $\mu \mathrm{m}$ fraction, not in the sand fraction. Their presence $(<1 \%)$ has been marked by crosses in Figure 3d. Only in Sample 366-25, CC, where radiolarians also have their highest values, are there $38 \%$ diatoms in the $40-63 \mu \mathrm{m}$ fraction. At Site 369 diatoms are found in those sections where radiolarians are present (Figure 2e)-Cores 369A-3 369-A-4, 369A-9 to 369A-13. The percentages of diatoms in the sand fraction are small (maximum $4 \%$ ), but they form up to $40 \%$ of the $40-63$ $\mu \mathrm{m}$ fraction.

Pteropods have only been found in four samples: Samples 369-1-1, 112-114 cm: 369-1-1, 141-142; with 10.4 and $0.5 \%$, respectively, and in $366-1-1(0.03 \%)$ and in $366-1, \mathrm{CC}(0.02 \%)$. The high sand fraction amounts in Section 369-1-1 are probably due to large amounts of well-preserved pteropods. Perhaps the pteropod abundance at Site 369 corresponds to the pteropod layer which has been found at the Pleistocene/Holocene boundary on the Ibero-West African continental slope (Kudrass, 1972; DiesterHaass et al., 1973; Diester-Haass, 1975b). Drilling 
disturbance is probably responsible for the presence of the pteropods.

Small amounts of fish debris are present in all samples. These are whole and broken fish teeth and parts of bones. Otoliths and scales are extremely rare.

At Site 369 fish debris forms $0.1 \%$ to $1 \%$ in Sections 369-1-1 to 369-5-4 (Figure 2f). In Sections 369-5-5 to $369 \mathrm{~A}-1-6$ they comprise up to $2 \%$ of the sand fraction. In the middle Miocene they are less than $0.5 \%$ and increase again in the early Miocene. In Cores 369A-12 and 369A-13 fish debris makes up more than $1 \%$, in 136 and $13, \mathrm{CC}$ it comprises $9.6 \%$ and $6 \%$ of the sand fraction, respectively. There are small amounts of fish debris in Section 366A-1-11 (Figures 3f), less than 1\% generally. In Cores $366 \mathrm{~A}-15$ to $366 \mathrm{~A}-17$ values increase to more than $1 \%$. In the early Miocene values range up to $0.5 \%$, the highest values correlating with the highest radiolarian and diatom amounts. Amounts of fish debris are less than $0.5 \%$ in Sections 368-1-1 to 368-6, CC (Figure 4f). In Sections 368-7-1 to 368-18, CC, it increases up to $32 \%$ where amounts of sand and calcareous tests, especially planktonic foraminifers are very low. Amounts of fish debris at Site 367 (Fibure 5f) vary between 0 and $1 \%$, except for two samples in Core $367-6$ which have more than $2 \%$.

Skeletons of benthic organisms found in the sediments are foraminifers, sponges, gastropods (caecidae), bivalves, ostracodes, echinoderms, balanus, and bryozoans. The amounts of total benthos are subject to great variations due to dilution by other components. As benthic foraminifers are by far the most important group, benthos amounts are shown as plankton/benthos ratios of foraminifers, calculated as benthic foraminifers/(benthic + planktonic foraminifers) $\times 100$. The variations in amount of benthos can be clearly seen from these curves (Figures $2-5 p)$.

Amounts of total benthos correlate well with the amount of sand: when the sand fraction is abundant, benthos percentages are low and vice versa. At Site 369 benthos generally forms $5 \%$ of the sand fraction, except in Sections 369-4-4 and 369A-1, CC and the intervals $369 \mathrm{~A}-3, \mathrm{CC}$ to $369 \mathrm{~A}-4-2,369 \mathrm{~A}-6-6$ to $369 \mathrm{~A}-7-1$, and $369 \mathrm{~A}-9-1$ to $369 \mathrm{~A}-13, \mathrm{CC}$, where values up to $20 \%$ occur. At Site 366 benthos percentages vary from $0.4 \%$ to $2 \%$ in Sections $366-1-1$ to $366-11-1$, from $1 \%$ to $5 \%$ in Sections $366-11-2$ to $366-18$, CC (with five values between 5 and $17 \%$ ), and from $<1 \%$ to $3 \%$ in Sections 366-19-1 to 366-27-6. At Site 368 benthos values are low $(<3 \%$ in Sections $368-1-1$ to $368-6, C C)$ In Sections $368-7-1$ to $368-12$, CC they comprise $3 \%$ to $48 \%$, and in Sections $368-13-1$ to $368-17$, CC, from $0.7 \%$ to $3 \%$. At Site 367 benthos forms less than $5 \%$ of the sand fraction except for Sections 367-1-2 (12\%), 367-1-4 (10\%), and $367-6$, CC (51\%).

Shell fragments of benthic organisms other than benthic foraminifers are very rare, generally less than 10 fragments per sample; therefore, their abundances are not shown graphically. Reference is only made to those samples where skeletons of benthic organisms (other than foraminifers) form statistically significant amounts of the sand fraction.

At Site 369 there are opal needles of sponges in Sections $369-10-1$ to $369-13$, CC, forming up to $1 \%$ of the sand fraction. These are sections in which radiolarians are found in large quantities. Caecidae, benthic gastropods, found by Sarnthein (1971) in the Persian Gulf in water depths shallower than 100 meters, are present in Sections 369-11-4 to 369-12-5 and 369-131 to $369-13-6$, forming up to $5 \%$ of the sand fraction or $>30 \%$ of total benthos (see Diester-Haass and Schrader, this volume). For Site 366 the same holds true as for Site 369: ostracodes and echinoids are minor amounts of the sand fraction $(<1 \%$, less than 10 skeletons per sample). Sponges, however, are present in greater amounts from Sections 366-16-5 to 366-27, CC, where radiolarians are abundant. Sponges form up to $80 \%$ of the total benthos. At Site 368 the radiolarian rich Sections 368-13-1 to 368-16, CC, also contain sponges, which make up to $100 \%$ of benthos, and up to $10 \%$ of the sand fraction. In Sections 367-5-1 and 367-5, $\mathrm{CC}$, there are bivalves (in 5-1 also balanus and bryozoans) together with relict shell material, indicating transport from shallow water.

Within the group of benthic foraminifers three different groups have been counted separately: imperforate, perforate calcareous foraminifers, and arenaceous foraminifers. The ratio of imperforate foraminifers/(imperf. + perf. for.) $\times 100$ is shown in Figures 2-5g. At Sites 369, 366A, and 368, imperforate foraminifers are present in the upper sections. The first appearance in Hole $366 \mathrm{~A}$ is in the middle of the late Miocene, apart from a few specimens in Cores 366A-14 to $366 \mathrm{~A}-16$ and approximately at the early/middle Miocene boundary at Site 368 (Cores 368-10, 368-11). At Site 369 they appear within the early Miocene (Core 369A-11) and increase at the middle/late Miocene boundary. So the first appearance of the imperforate foraminifers is at the northern Site 369. At Site 368 they appear later and the most recent appearance is at the southernmost Site 366 . The ratio shows an increase with water depth: $0 \%-15 \%$ at Site $369,10 \%-40 \%$ at Site 366 , and $10 \%-50 \%$ at Site 368 . There is no correlation between amount of imperforate foraminifers and fragmentation.

The amount of arenaceous foraminifers calculated as arenaceous foraminifers/(aren. + calc. for.) $\times 100$ is shown in Figures 2-5h. At Sites 369 and 368 values vary between 0 and $20 \%$ and between 0 and $10 \%$ at Sites 366 and 367. At Sites 369, 368, and 366, arenaceous foraminifers are rare in the lower early Miocene.

The term terrigenous material includes quartz, mica, and other minerals (feldspar and dark minerals). Dolomite, phosphorite, glauconite, and volcanic material have been counted separately. Two kinds of quartz have been distinguished: colorless quartz and quartz with yellowish red iron oxide coating. The latter comes from arid regions (Walker, 1967; Norris, 1969; Diester-Haass et al., 1973; Diester-Haass, 1975b). Following Radcewski (1937) the ratio (red quartz/colorless quartz) $\times 100$ is called the desert quartz number.

The terrigenous material has been counted as a percent of the $40-63 \mu \mathrm{m}$ and $>63 \mu \mathrm{m}$ fractions and is shown graphically in Figures 2, 4, and 5i. The curve showing the percentage of terrigenous material at Site 369 can be divided into four intervals (Figure 2i). In Sections 369-1-1 to 369-5, CC, and 369A-1-1 to 369A-3- 


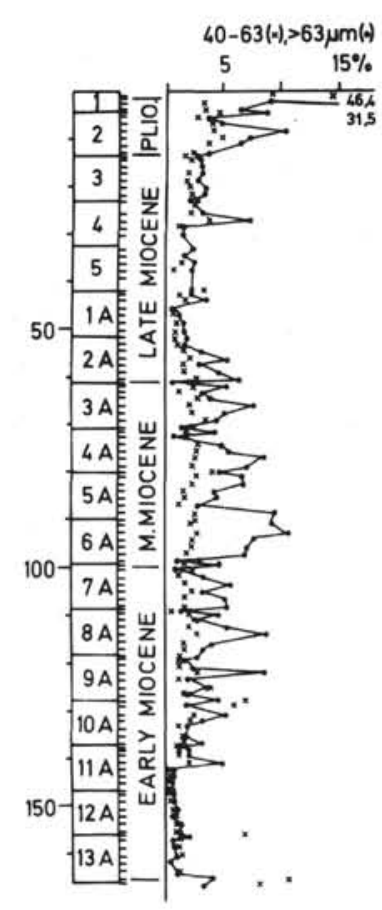

a

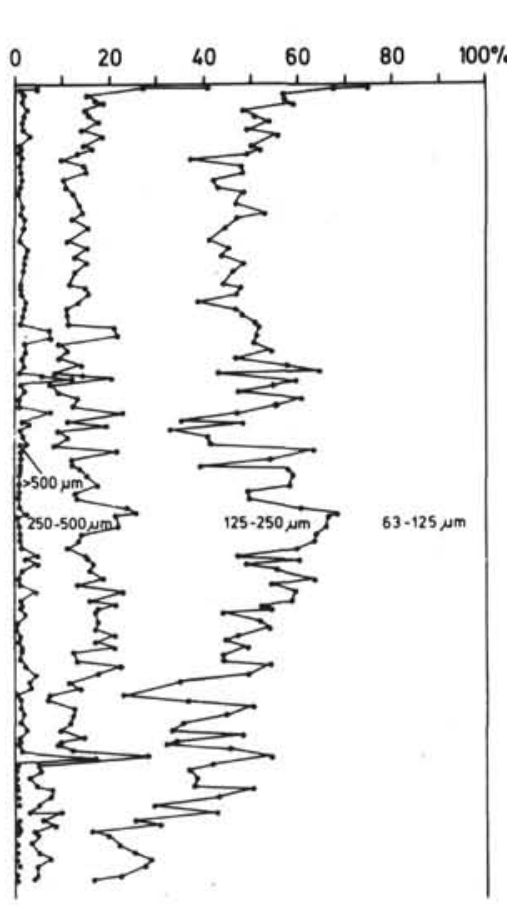

c

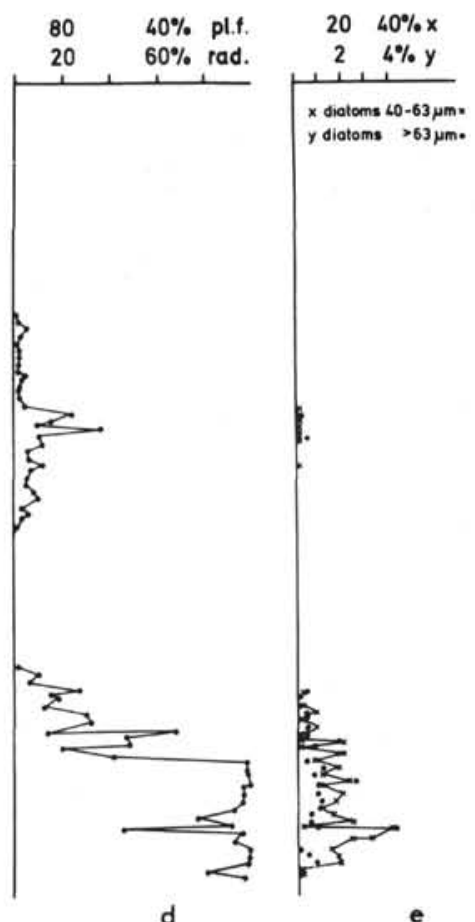

fish debris
$0 \quad 2 \%$

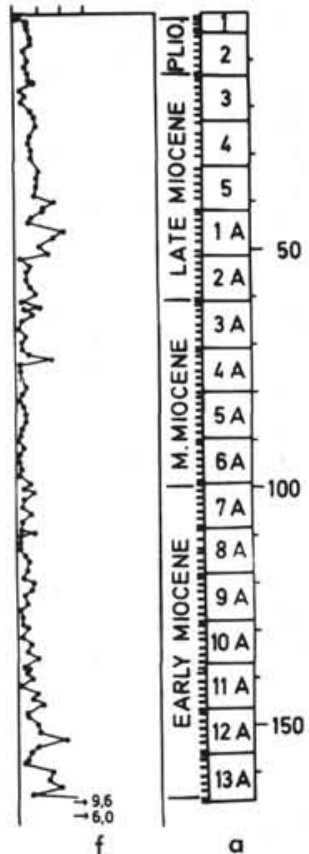

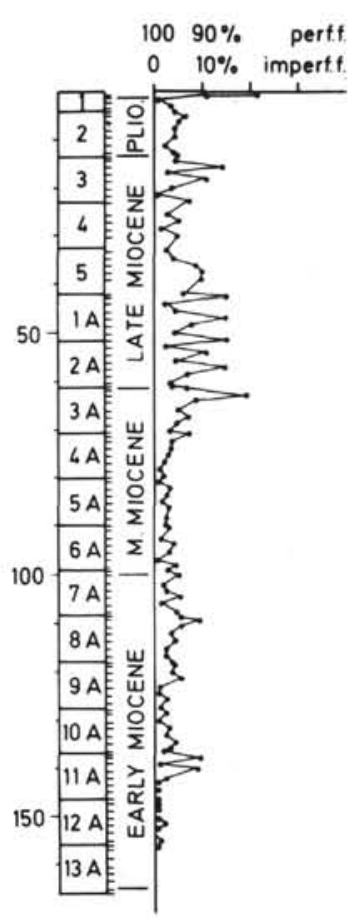

a

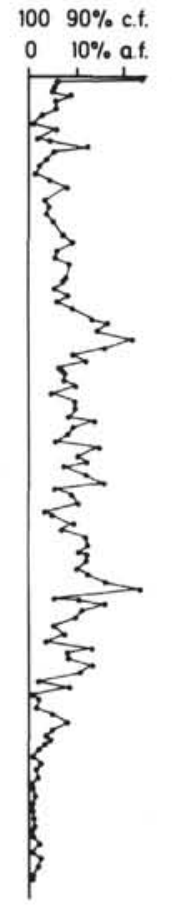

h

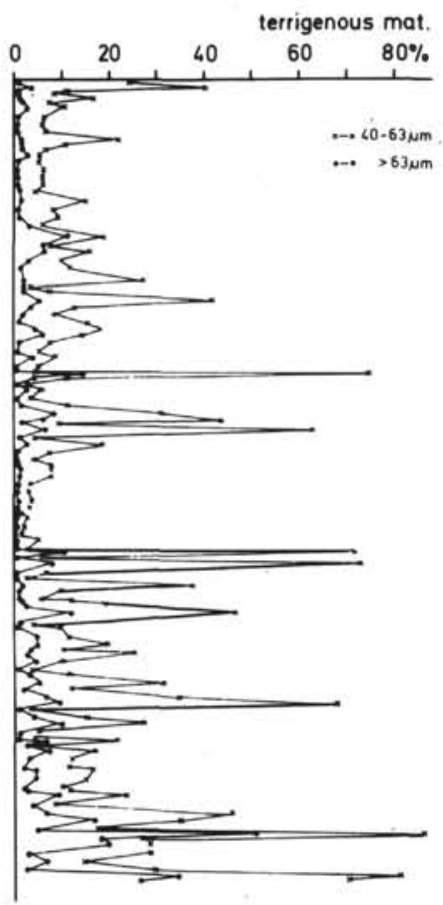

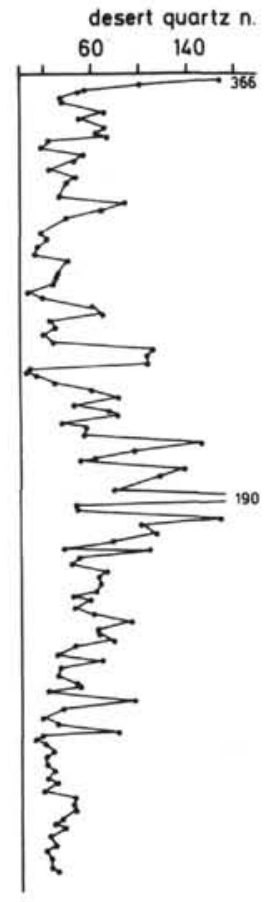

i

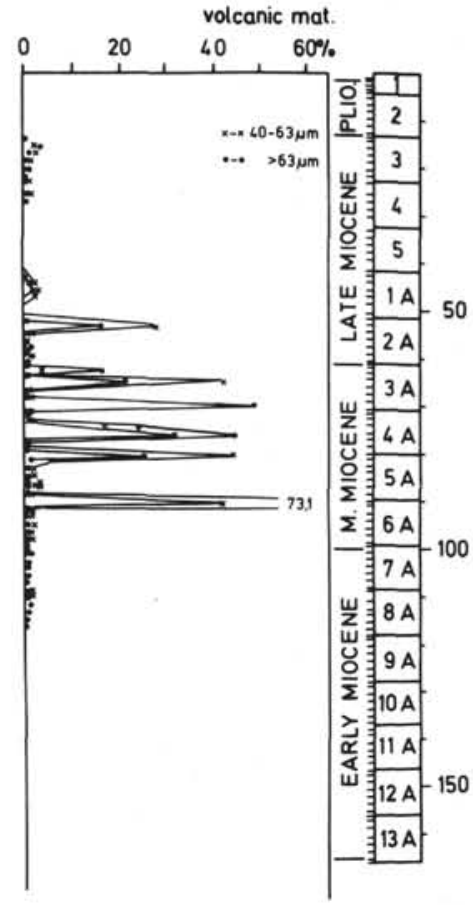

Figure 2. Results of Site 369. (a) Depth in meters below sea-floor; core number; Stratigraphy. Thin horizontal lines indicate position of investigated samples. (b) Amount of 40-63 $\mu \mathrm{m}$ and $>63 \mu \mathrm{m}$ fraction in percent of total sediment. (c) Grain size distribution within the sand fraction $>63 \mu \mathrm{m})$. (d) Radiolarian (rad.)/planktonic foraminiferal (pl.f.) ratio calculated as $\%$ radiol.

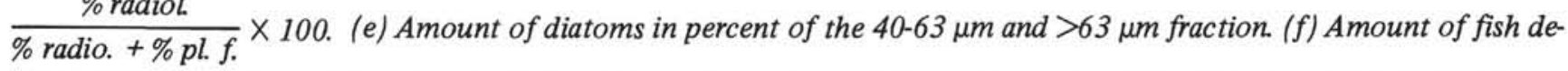
bris in percent of the sand fraction. (g) Ratio of imperforate (imperf.) to perforate (perf.) benthic foraminifers (for.) calculated as $\frac{\% \text { imperf. for. }}{\% \text { imperf. }+\% \text { perf. for. }} \times 100$. (h) Ratio of arenaceous (aren.) to calcareous (calc.) benthic foraminifers (f.), calculated as $\frac{\% \text { aren. } f .}{\% \text { aren. }+\% \text { calc. } f .} \times 100$. (i) Amount of terrigenous material in percent of the $40-63 \mu \mathrm{m}$ and $>63 \mu \mathrm{m}$ fraction. 


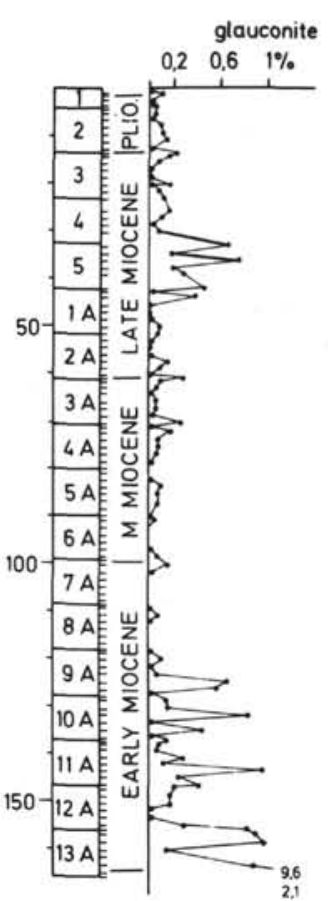

a

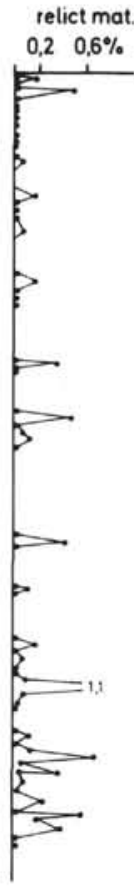

m

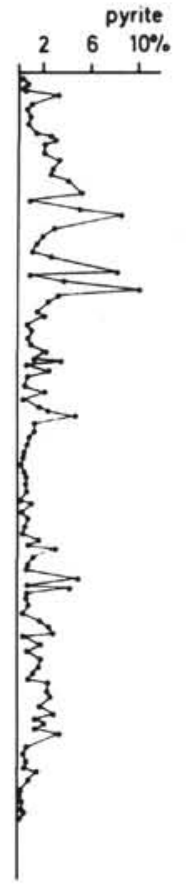

n

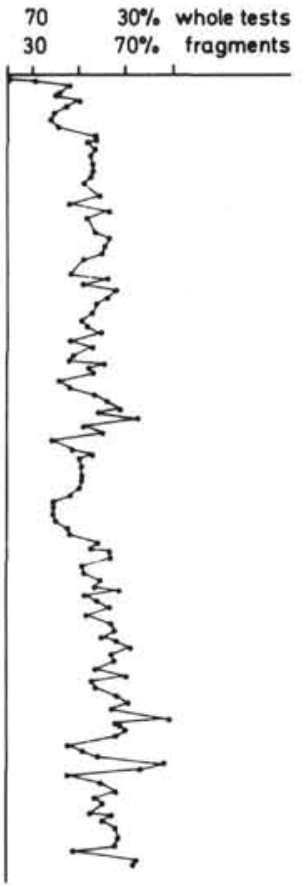

$\circ$

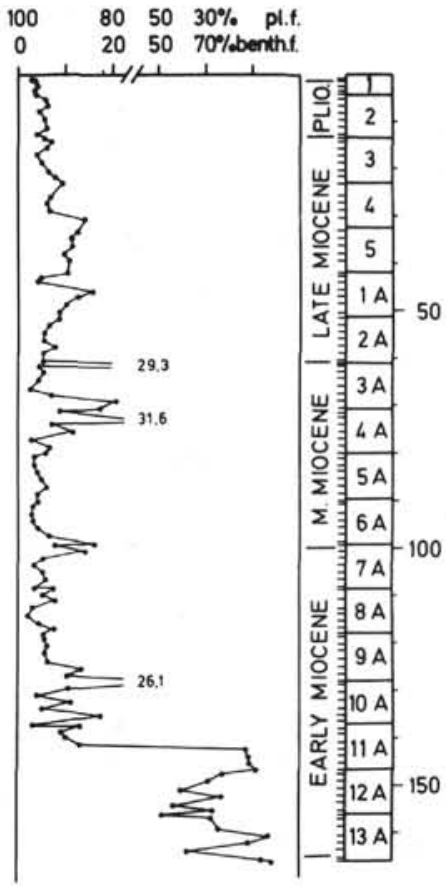

$p$

a

Figure 2. (Continued).

(j) Desert quartz numbers, calculated as $\frac{\text { red stained quartz }}{\text { colorless quartz }} \times 100$ (after Radczewski, 1939). (k) Amount of volcanic material in percent of the 40-63 $\mu \mathrm{m}$ and $>63 \mu \mathrm{m}$ fraction. (l) Amount of glauconite in percent of the 40-63 $\mu \mathrm{m}$ and $>63 \mu \mathrm{m}$ fraction. $(\mathrm{m})$ Amount of relict material in percent of the 40-63 $\mu \mathrm{m}$ and $>63 \mu \mathrm{m}$ fraction. $(\mathrm{n})$ Amount of pyrite in percent of the 40-63 $\mu \mathrm{m}$ and $>63 \mu \mathrm{m}$ fraction. (o) Fragmentaion of planktonic foraminifers in fractions $>63 \mu \mathrm{m}$, calculated as $\%$ fragments

$\%$ fragments $+\%$ whole tests

$\frac{\% \text { benth. } f .}{\% \text { plankt. }+\% \text { benth. }} \times 100$.

5 the amount of terrigenous material in the sand fraction varies between $1 \%$ and about $5 \%$, except for Sections $369-5-1$ to $369-5-3$, where between $7 \%$ and $10 \%$ are present. The percentages of terrigenous material in the $40-63 \mu \mathrm{m}$ fraction are $5 \%-20 \%$, except for a few samples with higher amounts (see Figure 2i). The second section is 369A-3-6 to $369 \mathrm{~A}-4-5$ where amounts of terrigenous material are high. The third section is 369 A-4-6 to 369A-6-6. Here amounts of terrigenous material are very low and show small variations. The fourth section is 369A-8-1 to 369A-13, CC. Here the maximum values are much greater than in the first interval. In the sand fraction they increase up to $50 \%$ and in the $40-63 \mu \mathrm{m}$ fraction up to $86 \%$. The maxima and minima follow more rapidly than in the first interval, which means that there have been considerable short time variations in terrigenous supply.

The curve showing desert quartz numbers (Figure $2 \mathrm{j}$ ) is roughly the mirror image of the curve showing amount of terrigenous material in the first interval (Section 369-1-1 to 369A-2, CC), with allowances for drilling disturbance. High amounts of terrigenous material correlate with low desert quartz numbers (Sections 369-2, CC to -3-1, -5-1 to -5-4, 369A-1-3, -1-4, and $-2, \mathrm{CC}$ to $-3-1)$. Here the desert quartz numbers are less than 20. Small amounts of terrigenous material, on the other hand, correlate with dessert quartz numbers of 30-100. In intervals 2, 3, and 4, desert quartz numbers are not below 20 and vary independently of the amount of terrigenous material. They are very high in interval 3 (Sections 369A-4-4 to $369 \mathrm{~A}-6, \mathrm{CC}$ ), and decrease in the third interval. The low values of $20-40$ in Cores 369A-11 to 369A-13 correlate with higher amounts of relict material and glauconite supplied from shallow water.

Site 368 has small amounts of terrigenous material in Sections $368-1-1$ to $-6, C C$, and $-9-1$ to $-10-2(<2 \%$ coarser than $63 \mu \mathrm{m},<20 \%$ in $40-63 \mu \mathrm{m}$ fraction (Figure $4 i)$. Here desert quartz numbers are high $(>50-1000$, Figure 4j). In Section 368-7-1 to -8, CC and -11-1 to 191 , the amounts of terrigenous material are higher. These are sections where the sand and the 40-63 $\mu \mathrm{m}$ fraction percentages are very low and calcareous fossils are rare. Desert quartz numbers are lower (less than $50)$. It is not known whether these low values are due to reduction of the reddish iron-oxide coating in these layers rich in pyrite (Cores 368-13 to 368-19). DiesterHaass (1975b) showed that with increasing amounts of pyrite the desert quartz numbers decreased. In Site 367 (Figures $5 i, j$ ), the amounts of terrigenous material vary 

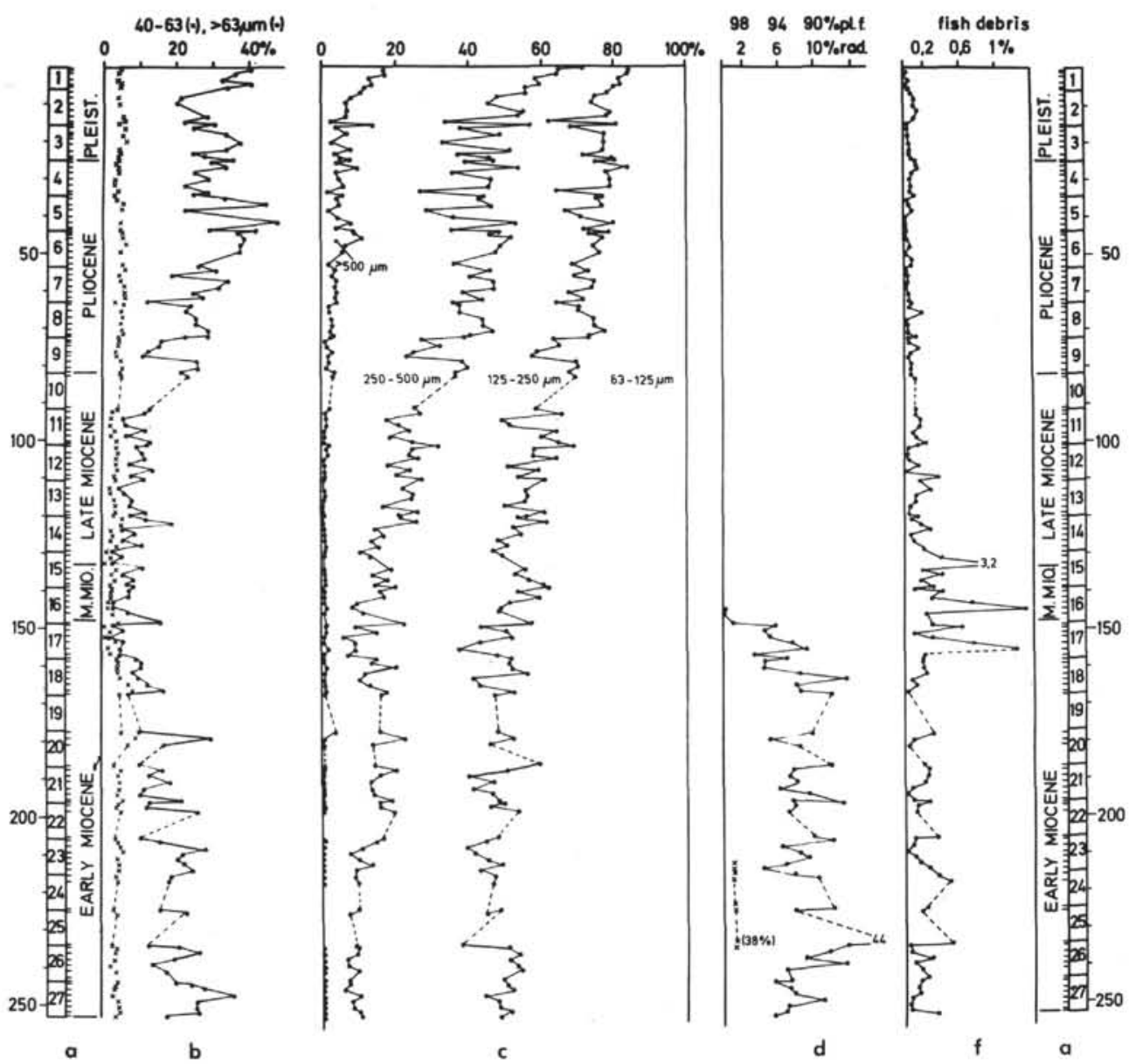
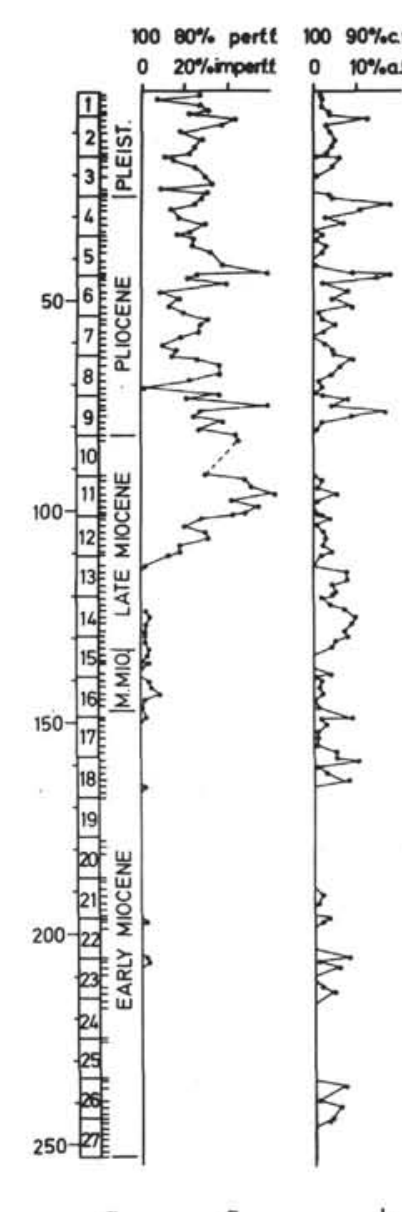

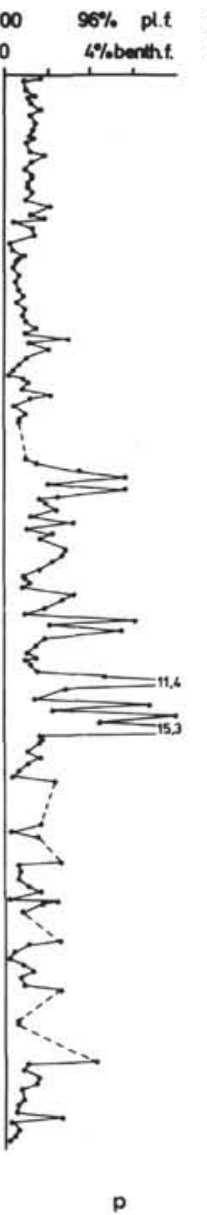

40\% wholo tests

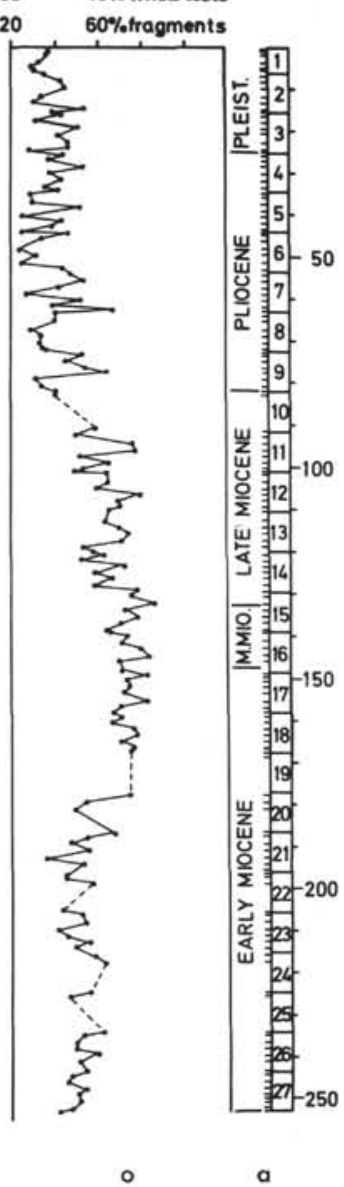

Figure 3. Results of Site 366. See Figure 2 for explanation of letters. 
from less than $1 \%$ to more than $90 \%$. Desert quartz numbers are high, always above 20, except for Sections 367-6-1 and 367-6, CC. At Site 366 there is no terrigenous material in the fractions $>40 \mu \mathrm{m}$.

Volcanic material has been found as yellow-brown volcanic glass and ash. At Site 369 (Figure 2k) there are small amounts of volcanic material in Cores 369-3 to -4, $369 \mathrm{~A}-1$, and -6 to -8 . In Cores $369 \mathrm{~A}-2$ to -5 some layers are poor and some are rich in volcanic material (up to $40 \%$, including one sample which has $75 \%$ in the $40-63$ $\mu \mathrm{m}$ and $>63 \mu \mathrm{m}$ fractions). At Site 366 no volcanic material larger than $40 \mu \mathrm{m}$ has been found. Less than $2 \%$ volcanic material has been found in fractions $>40$ $\mu \mathrm{m}$ from Cores $368-1,-4,-7$, and -10 (Figure $4 \mathrm{k}$ ). In Cores 368-13 to Section 368-17-1, amounts of volcanic glass increase up to more than $90 \%$ of the $40-63 \mu \mathrm{m}$ and of the sand fraction. At Site 367 only four samples contain volcanic material (Section 367-2-4 to $367-2$, $\mathrm{CC}$, with $1 \%$ to $2.5 \%$ of the sand fraction and $0.2 \%$ to $1.5 \%$ of the $40-63 \mu \mathrm{m}$ fraction, respectively).

Greenish-blackish grains which are sometimes polished have been counted as glauconite. They are supposed to have come from a shelf environment. Relict particles are worn, often bored, black, corroded, and sometimes glauconized shell fragments which have probably been transported downslope from a shallow water environment.

Glauconite forms less than $0.2 \%$ of the sand fraction of the upper part of Site 369 (Figure 2l), except for Sections 369-5-1 to 369-5, CC, where terrigenous supply is high. The higher values in Samples 369-2, CC, and 369-3, CC, and Section 369-7-1 also correlate with higher amounts of terrigenous material. Cores 369A-9 to -13 have higher glauconite values: up to $1 \%$, with values of $9 \%$ and $2 \%$ in $369-13-6$ and $-13, \mathrm{CC}$, respectively. This is the section with higher amounts of terrigenous material in the sand fraction. In Samples $369-12, \mathrm{CC}$, to $-13, \mathrm{CC}$, there is a very good correlation between glauconite and terrigenous material content in the sand fraction.

Amounts of relict particles are also very low, but they are shown graphically because their presence indicates supply from shallow water. Core 369-1 to 369-5, and $369 \mathrm{~A}-1$ to $369 \mathrm{~A}-8$ have relict particles in only a few samples (Figure 2m). In Sample 369-2, CC, and Sections $369-4-2$ and $369-6-6$ the values of about $0.4 \%$ correlate with peaks of terrigenous supply $(74 \%, 62 \%$, and $71 \%$ terrigenous matter in the $40-63 \mu \mathrm{m}$ fraction). In Cores $369 \mathrm{~A}-9$ to $369 \mathrm{~A}-13$ more samples contain relict material and percent values are higher. The increased amount of glauconite and relict particles in these cores points to higher supply from shallow water.

It is not known whether the glauconite formed during the early Miocene or whether it is reworked Eocene glauconite which has been described from this region (Tooms et al., 1971). At Site 366 no glauconite or relict material occur in $>40 \mu \mathrm{m}$ fraction. Site 368 has a few samples with some grains of glauconite: Sections $368-8-1$ to $-9-2(0.1 \%$ to $0.4 \%),-9, \mathrm{CC}$, to $-11-2(0.1 \%$ to $1.4 \%)$. There are no relict particles at Site 368 . At Site 367 glauconite occurs up to $11 \%$ and relict particles occur up to $5 \%$ which are higher than in the other cores (Figure $51, \mathrm{~m}$ ). Glauconite and relict particles correlate with each other and with the amount of terrigenous material. The relatively high amounts of relict material and glauconite together with high amounts of terrigenous material in the $>40 \mu \mathrm{m}$ fraction are interpreted as being due to turbidity currents, originating from shallow water (Diester-Haass et al, this volume).

Light brown to dark brown polished phosphorite grains occur in Sections 369-13-3 to 369-13, CC, with amounts of $0.5 \%, 0.3 \%, 2.0 \% 20.0 \%$, and $9.0 \%$ of the sand fraction, and $5 \%$ of the $40-63 \mu \mathrm{m}$ fraction. The age of formation is unknown, but it may have been during the early Miocene (see Diester-Haass and Schrader, this volume) or it may be reworked Eocene phosphorite (Tooms et al., 1971; von Rad, personal communication, 1976). At Site 367 phosphorite has been found in Section $367-5-1$. (36\% of $40-63 \mu \mathrm{m}$ fraction, $0.9 \%$ of sand fraction) and Sample $367-5, \mathrm{CC}(6.8 \%$ and $0.9 \%$, respectively). No phosphorite is present at Sites 368 and 366.

Dolomite occurs as colorless to faint yellow rhombs in the $40-63 \mu \mathrm{m}$ and $63-125 \mu \mathrm{m}$ fractions of Sites 369 and 368 . At Site 369 dolomite forms greater amounts in Section $369-13-6$ (1.8\% of the sand fraction and $7.1 \%$ of the $40-63 \mu \mathrm{m}$ fraction) and Sample $369-13, \mathrm{CC}(0.8 \%$ and $2.9 \%$ ). At Site 368 dolomite forms $3 \%-50 \%$ of the $40-63 \mu \mathrm{m}$ fraction and $0.3 \%-2.2 \%$ of the sand fraction in Samples 368-16-3 to 368-16, CC, and 368-17-2 to -17-4. At Sites 367 and 366 no dolomite occurs in the investigated size range.

The origin of the dolomite is unknown. It may have been formed in situ or it may have been transported from shallow water. The latter may be the explanation for Site 369, where some particles indicate transport from shallow water. Furthermore, the climate was arid during this period (see Discussion), and formation of dolomite in a hot and dry lagoonal environment may have been possible.

At Site 369 pyrite contents range between $1 \%$ and about $8 \%$ in Section 369-1-1 to Core 369A-1 and between $0.1 \%$ and $4 \%$ in the lower part. Lowest values are found in Cores $369 \mathrm{~A}-4$ to $369 \mathrm{~A}-6$, the interval with least amounts of terrigenous material (Figure $2 n$ ). The pyrite sometimes occurs as foraminifer and burrow casts, especially in the upper part (Section 369-1-1 to Core $369-4, C C)$. In most cases the pyrite surfaces are oxidized. It is probable that this oxidation occurred during preparation of samples with $\mathrm{H}_{2} \mathrm{O}_{2}$. Sometimes minute pyrite crystals could be observed on foraminifer surfaces. In the lower part (from about Cores 369A-1 to $369 \mathrm{~A}-12)$ pyrite is mostly framboidal. At Site 366 no pyrite has been found. Pyrite is completely absent in the upper part of Site 368 (Figure 4n). In Core 368-11 pyrite appears and amounts increase up to $100 \%$ of the sand and $40-60 \mu \mathrm{m}$ fraction in Cores 368-17 to 368-19. In these cores calcareous fossils are lacking. Radiolarians, fish debris, and quartz occur in small amounts accompanying the pyrite. The pyrite occurs as large crystals and aggregates of crystals up to $1 \mathrm{~mm}$ in diameter. At Site 367 pyrite occurs in Section 367-2-2 to Sample $367-2$, CC $(0.3 \%, 1.1 \%$ of the sand and $0.6 \%$ of the $40-63 \mu \mathrm{m}$ fraction) and in Sections 367-6-1 (3.2\%) and $367-6, \mathrm{CC}$ (1.4\% of the sand fraction). 


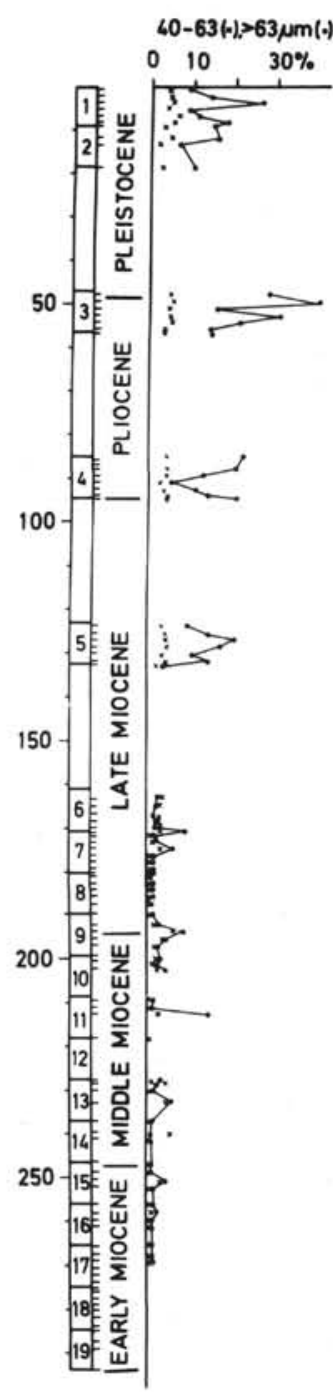

b
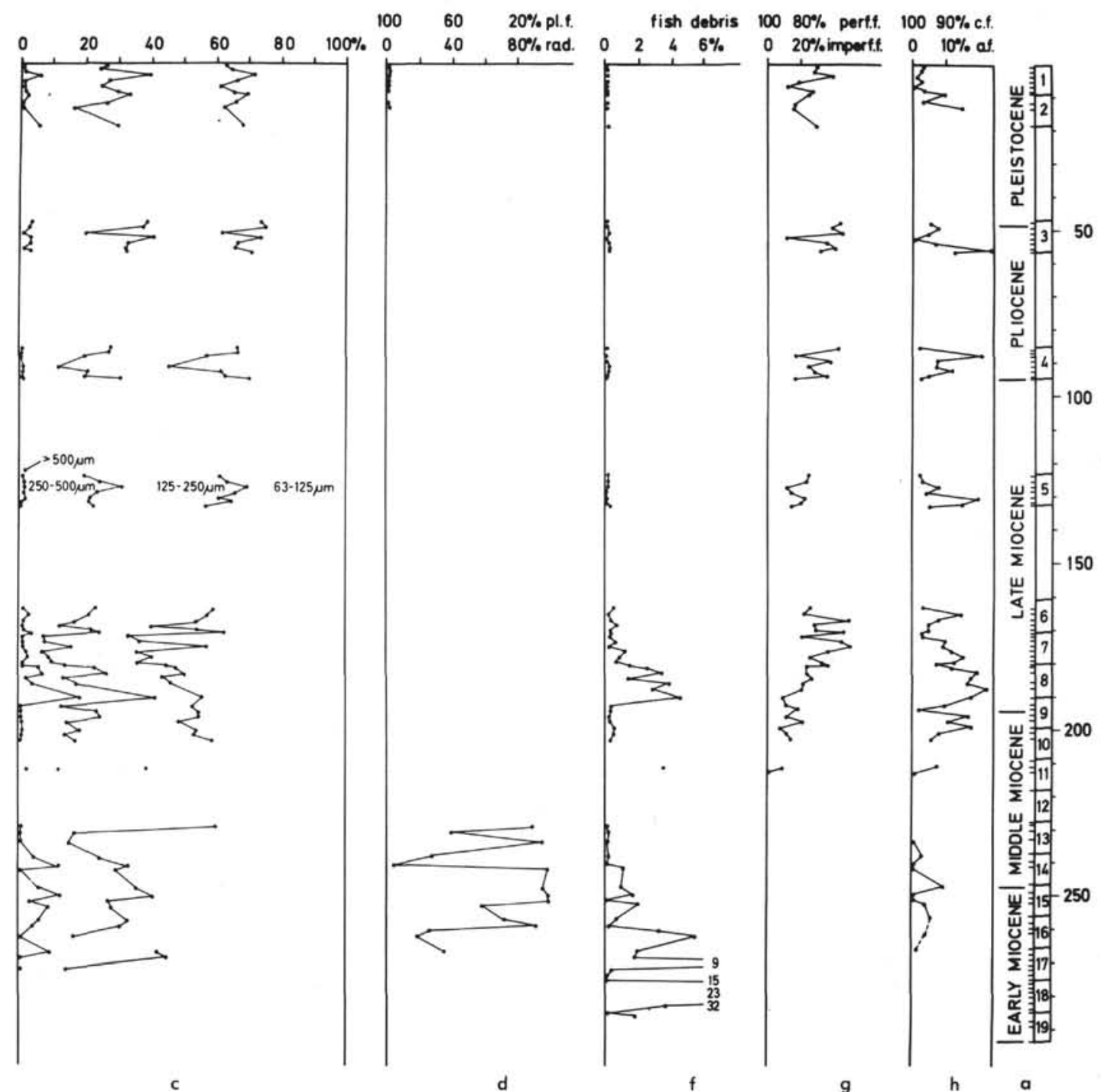

Figure 4. Results of Site 368. See Figure 2 for explanation of letters.

\section{FRAGMENTATION OF PLANKTONIC FORAMINIFERS}

With increasing dissolution of calcium carbonate, planktonic foraminifers become more and more fragmented. The number of whole tests decreases (Arrhenius, 1952; Berger, 1973; Berger and von Rad, 1972; Diester-Haass, 1975a). Thus, the ratio (fragments/fragments + whole tests) $\times 100$ can indicate the amount and variation of $\mathrm{CaCO}_{3}$ dissolution. In Figures 2-5o, the fragmentation is given only for the sand-sized planktonic foraminifers. Fragmentation variations in the $40-63 \mu \mathrm{m}$ fractions are parallel but with higher values.

At Site 369 (Figure 2o) fragmentation is low in the Plio-Pleistocene section (Cores 369-1 and 369-2) with values $<40 \%-50 \%$. In Section 369-3-1 to Sample 369-5, $\mathrm{CC}$, and Cores $369 \mathrm{~A}-1$ to $369 \mathrm{~A}-2$ fragmentation has a middle value of $55 \%$. In the lower part of Core $369 \mathrm{~A}-3$ and upper part of Core $369 \mathrm{~A}-4$ it increases to $>70 \%$ and has low values in Cores 369A-5 to 369A-6 $(<40 \%$ $50 \%$ ). From Cores $369 \mathrm{~A}-7$ to $369 \mathrm{~A}-10$ it increases to about $70 \%$ and has an average value of about $60 \%$ in Cores $369 \mathrm{~A}-11$ to $369 \mathrm{~A}-13$. The general trend of the fragmentation curve of Site 366 is similar to that of Site 369 (Figure 3o). Lowest values occur in the PlioPleistocene section (Cores 366-1 to 366-9) with mean values of about $30 \%-40 \%$. As at Site 369 a rapid increase occurs towards the late Miocene which correlates to increased diagenesis (Futterer, this volume). Constant values are found in the latelMiocene (Cores $366-11$ to $366-14$, mean values about $60 \%$ to $70 \%)$. The middle Miocene, very thinly developed here (Sections 366-15-3 to 366-16-5), has, like Site 369, very high values in the upper part (85\%) and low values in the lower part $(65 \%)$ and an increase towards the beginning of the middle Miocene. There are high values in the upper early Miocene (about $75 \%$ in Cores 366-16 to 366-18) and lower ones in the lower early Miocene $(40 \%-60 \%)$. The increased amounts of fish debris in Cores $366-15$ to $366-17$ correlate with the zone of highest fragmentation. The four samples with fish debris maxima are those in which fragmentation exceeds $80 \%$. Absolute values of fragmentation are 


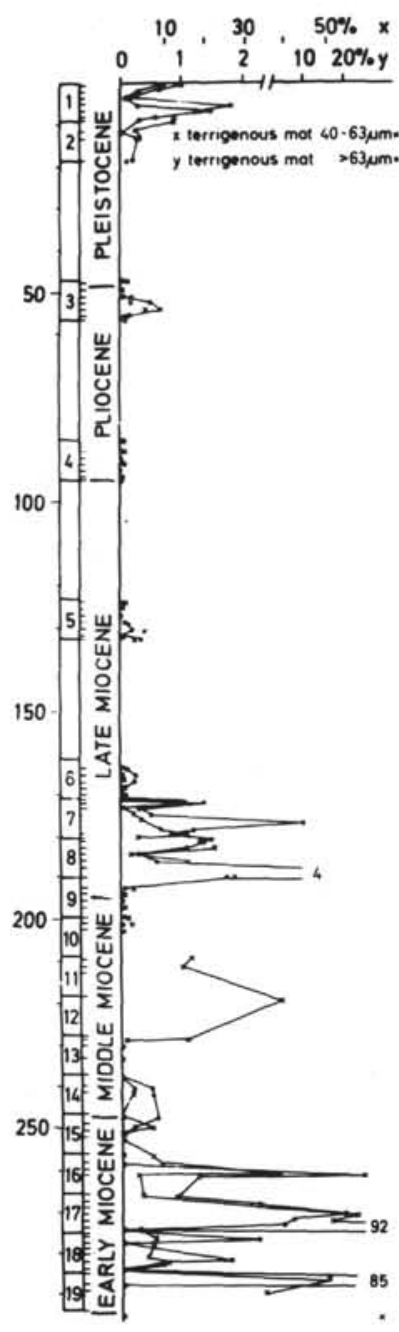

a

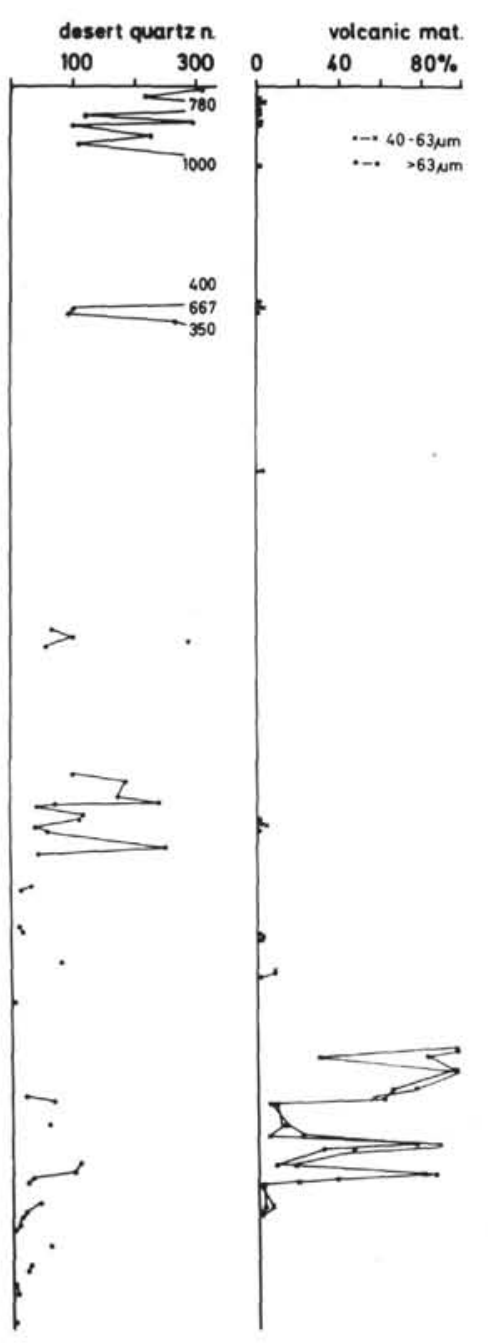

i

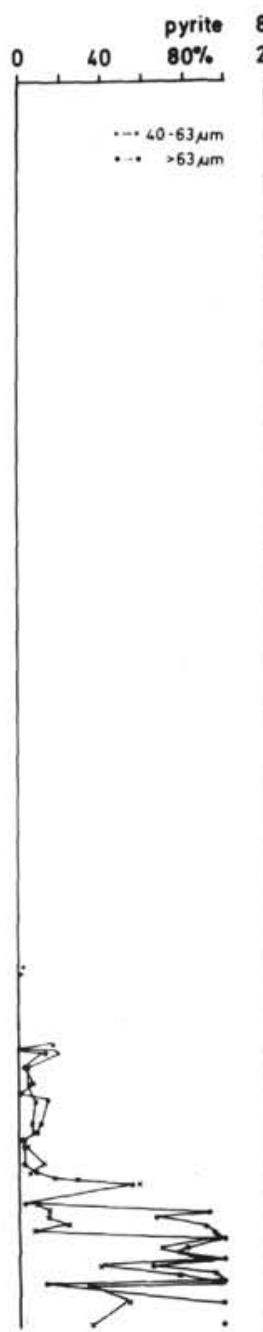

u

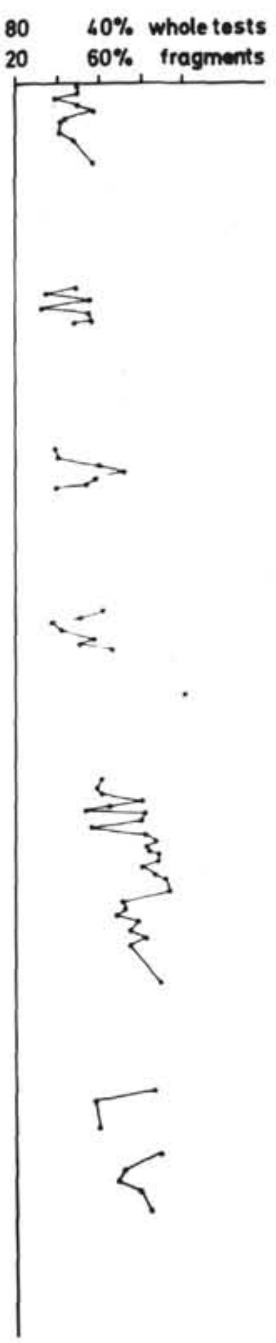

$\circ$

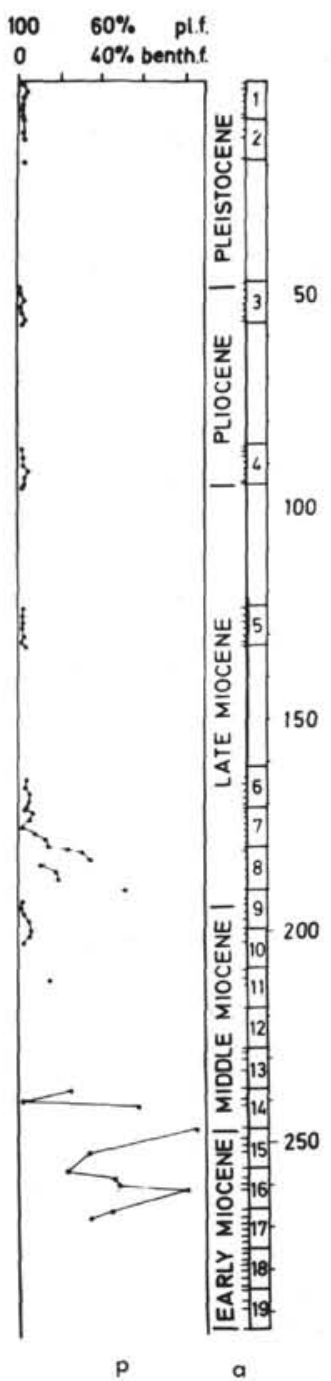

Figure 4. (Continued).

higher at Site 366 than at Site 369 , except for the lower early Miocene and some samples in the late Miocene. For Site 368 the same holds true as for Site 366 and Site 369 (Figure 4o): low fragmentation in the PlioPleistocene. In the lower late Miocene fragmentation increases to $>90 \%$. Two samples from the lower middle Miocene, containing abundant planktonic foraminifers, have low fragmentation $(60 \%)$, as have Sites 366 and 369. In Cores 368-17 to 368-19 foraminifers are sparse or absent. Amounts of fish debris correlate exactly with the degree of fragmentation as at Site 366. The high values in Core $368-8$ correlate with fragmentation values of $>80 \%$. In Core 368-9, Sections 368-14-2, -14, CC, and -16-2 with low fragmentation, there is little fish debris. The few cores from Site 367 (Figure 5o) do not allow trends of fragmentation to be traced. However, a decrease in fragmentation from $99 \%$ in Core $367-2$ to $75 \%$ in Core $367-1$ can be observed.

There is a striking correlation between fragmentation and percent sand fraction of total sediment in all cores (compare Figures 2-5o with Figures 2-5b). High fragmentation corresponds to low sand values and vice versa. The same has been observed by Cita (1971) in the
Pliocene of Site 12 off northwest Africa. The trends of coarse sand fraction, $>125 \mu \mathrm{m}$, also correlates with fragmentation (compare Figures 2-50 with Figures 2$5 \mathrm{c})$. High fragmentation correlates with small amounts of coarse sand fraction and higher amounts of the 63$125 \mu \mathrm{m}$ fraction.

\section{BENTHOS/PLANKTON RATIOS OF FORAMINIFERS}

Benthic foraminifers are more resistant to dissolution than planktonic ones (Arrhenius, 1952; Berger, 1973; Diester-Haass, 1975a) and so the planktonic/benthic ratio decreases with increasing dissolution. This forms a useful tool for evaluation of dissolution effects. Here the ratio has been calculated as (benthic foraminifers/benth. + planktonic foraminifers) $\times 100$ and is shown in Figures 2-5p. There is a good positive correlation in all sites between fragmentation of planktonic foraminifers and this ratio. This observation has also been made by Cita (1971). This correlation is not only for the general trend but often in details, for instance Cores $368-3$ to $368-10,369 \mathrm{~A}-1$ to $369 \mathrm{~A}-9$, $366 \mathrm{~A}-7$ to $366 \mathrm{~A}-18$. The only exception is Cores $369 \mathrm{~A}$ 11 to $369 \mathrm{~A}-13$ where benthics increase to $>90 \%$ while 


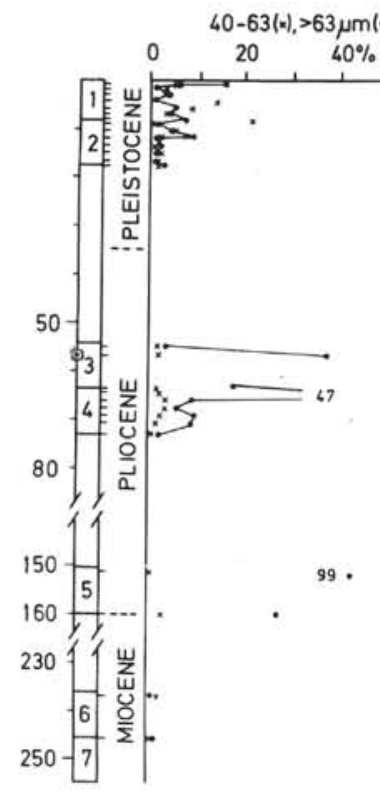

a

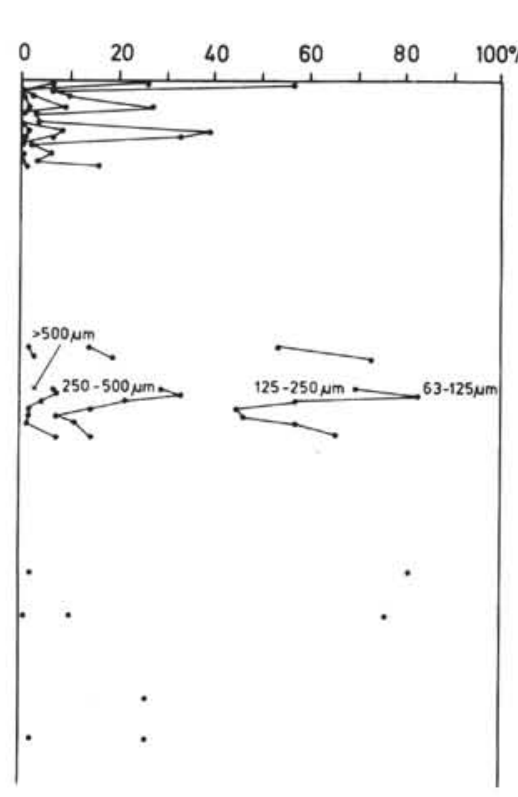

c

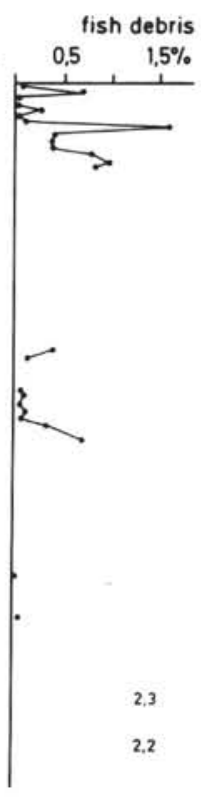

$f$

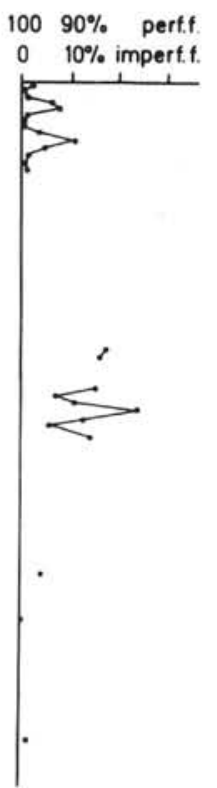

g

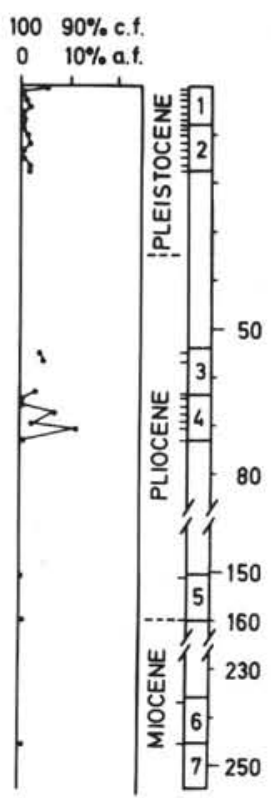

h a

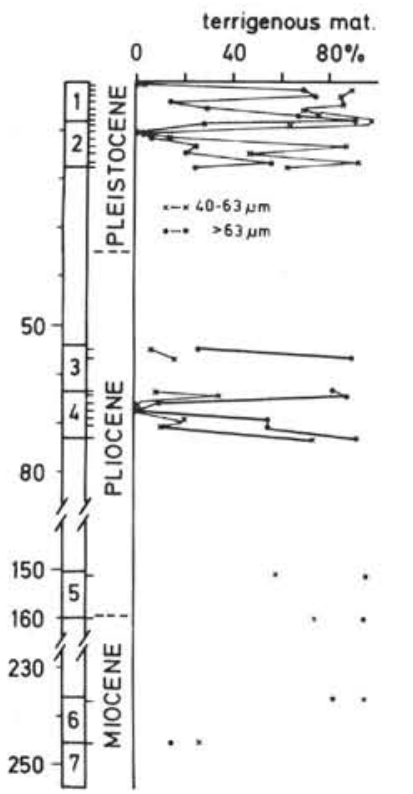

a

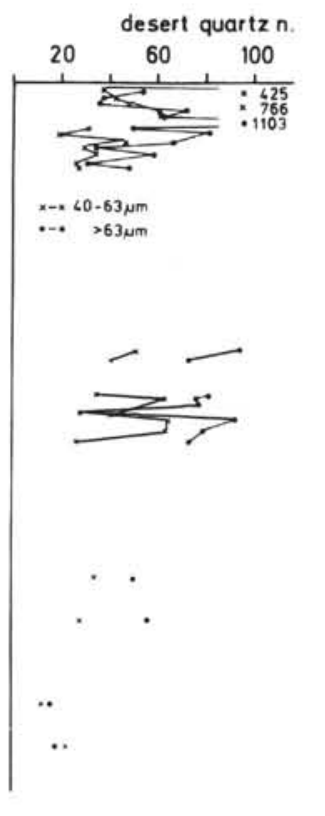

i

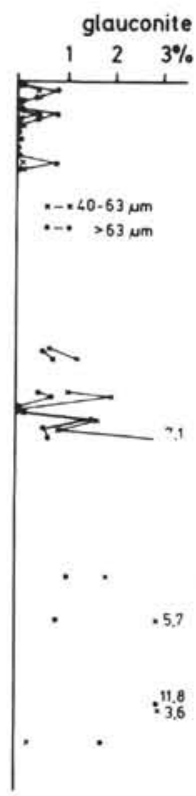

I

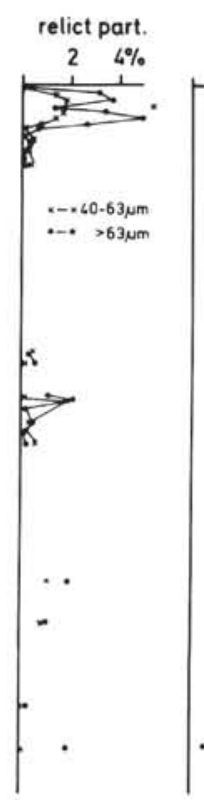

m

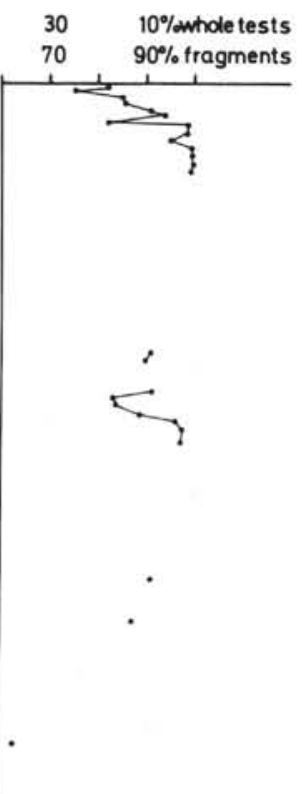

$\circ$

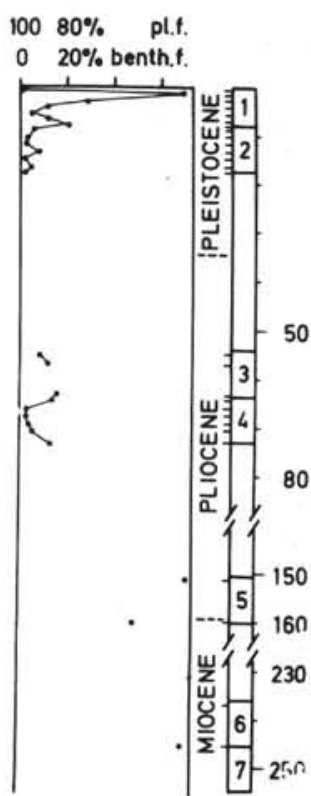

p

a

Figure 5. Results of Site 367. See Figure 2 for explanation of letters.

fragmentation does not increase (see Diester-Haass and Schrader, this volume).

The absolute values of benthic foraminifers in percent of benthic plus planktonic foraminifers are highest at the shallowest site (3-15\%, maximum $30 \%$, in Cores 369 A-11 to 369 A-13, 50-90\%). Site 366, about 1000 meters deeper than Site 369 , has smaller values $(<2 \%-6 \%$, maximum $15 \%)$. The values at Site 368 , about 500 meters deeper than Site 366, are lower in the upper sections (in general 1\%-2\%), but they are much higher in Cores 368-6 to 368-17, where fragmentation is greater (up to $60 \%$ benthics). At the deepest site (Site
367 ) benthic foraminifers make up $2 \%-20 \%$ of the sum benthic plus planktonic foraminifers and thus values are in the same range as those in the shallowest site.

\section{DISCUSSION}

\section{Carbonate Dissolution}

The influence of calcium carbonate dissolution can be deduced from the data presented on planktonic foraminifer fragmentation and on benthic/plankton ratios of foraminifers. With increasing dissolution planktonic foraminifers become more fragmented. The 
benthos/plankton ratio of foraminifers depends on three factors: (1) water depth increasing water depth produces smaller numbers of benthics; (2) fertilityDiester-Haass (in 1976b) showed that with increasing fertility in the surface water, the accumulation rate of benthic foraminifers increases; and (3) dissolution-with increasing dissolution benthic foraminifers increase relative to planktonic ones. The influence of water depth can be seen by the fact that at Site 369 benthics are more abundant than at Site 366 . At Site 368 the cores with low fragmentation have still lower values than the shallower Site 366 . The influence of fertility is difficult to evaluate. In Cores 369A-9 to $369-\mathrm{A}-13$, high fertility from upwelling is supposed to determine sediment properties (see Diester-Haass and Schrader, this volume). Here benthic values increase drastically. Simultaneously, shallow water particles such as relict material, dolomite, and glauconite increase. Thus, the increase in fertility, shallow water supply, or both, are responsible for the increase in benthic foraminifers.

The curves showing fragmentation (Figures 2-5o) and benthic/planktonic ratios (Figures 2-5p) show variations in carbonate dissolution in the Neogene. The curves of the continuously cored Sites 369 and 366 are approximately parallel. Slight dissolution is indicated for the lower early Miocene, increasing towards the upper early Miocene, falling in the lower middle Miocene and increasing to highest values in the upper middle Miocene, then decreasing again in the late Miocene and decreasing sharply in the PliocenePleistocene. Plio-Pleistocene fragmentation values are smaller than in the lower early Miocene. Site 368 also shows the least dissolution influence in the PlioPleistocene and upper late Miocene. The lower late Miocene has high fragmentation as have Sites 366 and 369. Two samples from the early middle Miocene also correlate with the observation from Sites 366 and 369 in that they show small fragmentation. The early Miocene of Site 368 contains only infrequent or no foraminifers, the sand fraction consisting mainly of pyrite.

Accumulation rates described for Hole $366 \mathrm{~A}$ by Dean et al. (this volume) correspond well with the variations in carbonate dissolution. Accumulation rates of $17.5 \mathrm{~m} / \mathrm{m} . \mathrm{y}$. are described for the Plio-Pleistocene section, where preservation of foraminifers is best, 9 $\mathrm{m} / \mathrm{m} . \mathrm{y}$. for the late Miocene, and lowest values for the middle Miocene $(2.5 \mathrm{~m} / \mathrm{m} . \mathrm{y}$.$) , where fragmentation$ and thus dissolution is highest. Accurnulation rates increase again to $14 \mathrm{~m} / \mathrm{m} . \mathrm{y}$. in the early Miocene, where preservation of foraminifers is better than in the middle Miocene. At this site with small terrigenous input accumulation rates are influenced mainly by variations in carbonate dissolution.

This general trend of variation in carbonate dissolution correlates well with the variation in depth of the calcium carbonate compensation depth (CCD), as described by Berger and von Rad (1972) for this region. Following these authors, the CCD shifted from 4500 meters in the lower early Miocene to about 3600 meters in the upper early Miocene-lower middle Miocene. This corresponds to an increase in carbonate dissolution at Sites 366 and 369 . Only in the lower middle Miocene is low fragmentation not reflected in an increase in depth of the CCD. In the late Miocene the CCD shifts downward as do fragmentation values. Lowest fragmentation is observed in the Plio-Pleistocene sections, where the CCD reaches the deepest level of about 5000 meters.

Two questions arise from these findings: (1) by which mechanism does the degree of carbonate dissolution (as described by fragmentation of planktonic foraminifers and benthos/plankton ratios of foraminifers in samples far above the CCD) correlate with depth variations of the CCD?. Perhaps Site 369 lies within the lysocline depth (Berger, 1968), which probably shifted parallel to the CCD. On the continental slope, the lysocline and CCD are supposed to be much shallower than in oceanic regions and the distance between the levels is greater (Berger, 1970, 1971). A CCD distinctly rising towards the continent during Miocene has been mentioned by Berger (1974). This explanation does not hold true for Site 366, however, since it is situated on the Sierra Leone Rise, far away from the continental slope (Dean et al., this volume). (2) Which factors are responsible for the changes in depth of the CCD? The CCD changes during the Tertiary are parallel, not only in the North and South Atlantic, but also in the Indian Ocean and approximately in the Pacific Ocean (Berger and Winterer, 1974; van Andel, 1975). These authors believe that mainly global factors, transgressions and regressions, are responsible for shoaling and deepening of the CCD. During a transgression, carbonate input to the deep sea is reduced by shallow water extraction of carbonate and so the CCD will rise. In fact, the rise of the CCD from lower to middle Miocene might be due to a major transgression (see section on sea level). Regressions due to glacial advances in Antarctica may have occurred since early Miocene (Pimm and Hayes, 1972). Berger and Winterer (1974) mention some additional factors, among others the paleotemperature, which might influence the mean global depth of the CCD. In fact, the curve of Savin et al. (1975) showing Tertiary marine paleotemperatures, resembles the CCD curve in Berger and von Rad (1972) for the Atlantic during the Tertiary. Ramsay (1974) also found a correlation between depth of the CCD and paleotemperatures. His curves of the Neogene CCD in the Pacific and Atlantic, however, are quite different from those of Berger and von Rad (1972) and van Andel (1975). Changes in fertility and thus in dissolution may also be responsible for varying depths of the CCD.

The described carbonate dissolution variations are responsible for variations in amount of other components, and in grain size. The amounts of sand fraction and coarse fractions within the sand fractions correlate with fragmentation variations. With increasing dissolution, planktonic foraminifers break down, become smaller, and the observed variations in grain size are produced. With increasing dissolution of planktonic foraminifers, dissolution-resistant particles are enriched in the coarse fractions, such as benthic foraminifers, fish debris, and perhaps quartz (mainly Site 368). This is responsible for the difficulty in interpretation of the percentage values of the noncarbonate particles because they do not reflect production or supply but mainly varying dilution by carbonate particles, largely planktonic foraminifers. 


\section{Neogene Climate In Northwest Africa As Deduced From Site 369}

The amount of terrigenous material and the desert quartz numbers can give indications of climatic variations. Only Site 369 will be considered in detail here, because at Site 366 there is no terrigenous material $>40 \mu \mathrm{m}$ and because Sites 368 and 367 are not continuously cored. Climatic variations in northwest Africa during the late Quaternary have been detected by analysis of the terrigenous material in the coarse fraction from sediment cores off northwest Africa (Diester-Haass, 1975b, 1976a, Diester-Haass et al., 1973). In northwest Africa $\left(20-27^{\circ} \mathrm{N}\right)$ Holocene and older interglacial periods had an arid climate with mainly wind transport of the terrigenous particles. As wind cannot transport particles $>80 \mu \mathrm{m}$ in suspension (Bagnold, 1954), the amount of terrigenous material in 40-63 $\mu \mathrm{m}$ fractions is small and is almost absent in fractions $>63 \mu \mathrm{m}$. Desert quartz numbers are high ( $>$ 20 ), due to the arid climate in the African hinterland. During glacial periods the climate was humid in northwest Africa north of $20^{\circ} \mathrm{N}$ and rivers transported terrigenous material to the ocean. Amounts of quartz and other minerals are much higher than during arid periods, due to greater transport energy of rivers compared to the wind. Desert quartz numbers are low $(<20)$.

Assuming that these findings can be applied to the Neogene sediments of the same region, the following climatic evolution during the Neogene is obtained (Figures 2i, and j). In the upper part of Site 369 (Cores 369-1 to 369-5 and Core 369A-1 to Section 369A-3-5) the climate was similar to that during the late Quaternary. Humid periods with rainfall on the continent, and thus rivers, are reflected in large amounts of terrigenous material and low desert quartz numbers. Arid periods are reflected in smaller amounts of terrigenous material in coarse fractions and higher desert quartz numbers. Absolute values of terrigenous material and desert quartz numbers are similar to those for the late Quaternary sediments from the same region where desert quartz numbers are in general between 30 and 100 in arid periods and less than 20 in humid periods (Diester-Haass, in 1976a). In the middle part of Site 369 (Sample 369A-4, CC to Section 369A-6-6), the amount of terrigenous material in $40-63 \mu \mathrm{m}$ and $>63$ $\mu \mathrm{m}$ fractions is very small, and desert quartz numbers increase to $>100$. This is interpreted as reflecting an arid climate on the continent with formation of large amounts of red quartz and only wind supply of terrigenous components. High desert quartz numbers with larger amounts of terrigenous material $>40 \mu \mathrm{m}$ in Sections $369 A-3-6$ to $369 A-4-5$ are due to arid climate and probable supply of eolian sand by turbidity currents.

In the lower part of site 369 (Cores 369A-8 to 369A13) two observations are important. First, a rapid change between sediment layers with low and high amounts of terrigenous material and secondly, desert quartz numbers being above 20 throughout the section. Thus, it is concluded that climate has been arid during this period. But it is highly questionable whether wind strength was strong enough to transport the large amounts of sand-sized and 40-63 $\mu \mathrm{m}$ sized quartz grains. It is supposed that during this period another transport mechanism intervened, namely turbidity currents. The following origin for the layers rich in coarse terrigenous material of this section is proposed (see Sarnthein and Diester-Haass, 1976): sea level has been lower during this period and dunes could spread over the shelf, blown by strong offshore winds; the dunes were reworked at the shelf edge and slid down as eolian-sand turbidites, which are interbedded with normal hemipelagic sediments.

The general decrease in desert quartz numbers from about 80 in Core 369A-8 to 20 to 30 in Cores 369A-11 to $369 \mathrm{~A}-13$ is probably not due to variations in climate but to dilution by colorless quartz from shelf or coastal regions. It is the same section where shallow water particles such as glauconite, dolomite, relict material, and benthics increase considerably, indicating a greater importance of shallow water supply. It is assumed that together with this material, shallow water quartz grains without coating are mixed with the pure desert sand. Those layers which have large amounts of terrigenous material have in general larger amounts of shallow water particles and lower desert quartz numbers.

Site 368 has high desert quartz numbers in Cores 368 1 to 368-7 which are of late Miocene to Pleistocene age, pointing to an arid climate. It is not known, however, whether humid periods occurred in those parts which have not been cored.

If these deductions from late Quaternary sediments to Neogene conditions are correct, one can conclude that the Sahara Desert existed already in the early Miocene. Climate was arid during early and middle Miocene and a change occurred in late Miocene with the appearance of humid periods with rainfall and river supply which alternated with arid periods, as in late Quaternary times. Climatic interpretation of lower Miocene sections of Sites 139 and 140 is indicative of an arid period with strong off-shore winds (Sarnthein and Diester-Haass, 1976). Pflaumann (this volume) describes a cold period in Core 369-5. This cold period correlates to an extensive humid period. The climatic conditions found at Site 369 (and Sites 139 and 140) in the lower Miocene correspond to those found during the last glaciation off Senegal. The paleolatitude of Site 369 in early Miocene was probably much farther south than today. This agrees with Berger and von Rad (1972), who describe a paleolatitude of about $15^{\circ} \mathrm{N}$ for Sites 139 and 140 . Site 369 , about $7^{\circ} \mathrm{N}$ farther north today, would have been situated in the center of the early Miocene tradewind belt.

It is rather difficult to find a correlation between climatic results from DSDP results off northwest Africa and sediments on the northwest African continent. There are three major problems: lack or sparsity of fossils in the sediments on the continent; difficulty of interpretation of the sequences; and difficulty of dating the sediments (for further literature see Monod, 1963).

During the Mio-Pliocene the "Continental Terminal" was deposited in western Africa, which was formed under arid continental conditions (Elouard, 1959; Monod, 1963; Schwarzbach, 1954). Michel (1973) attributes the formation of the "Continental Terminal" in the Senegal-Gambia Basin to a subarid climate with 
sparse vegetation and a more humid period during Oligocene-Miocene (?) time. The "Continental Terminal" in the Ivory Coast region has a fluvial origin (Tastet, 1971). Tessier et al. (1975) believe that the "Continental Terminal is a series of marine sediments with a thick fringe of weathering.

The region north of the Sahara had an arid climate, at least during parts of the Tertiary, as has been concluded from salt and gypsum deposits and from silicified wood (Schwarzbach, 1954; Cornelius, 1971). The latter author concludes from an analysis of migrating plates that the Sahara Desert occupies the same region today as during Oligocene and upper Miocene. Finally, the sparse climatic indications available from the African continent are not in contradiction to the findings from Site 369 .

\section{Sea-level Changes}

It has been found in late Quaternary sediments off northwest Africa that glauconite and relict particles from shelf environment are more abundant in continental slope sediments during periods of lower sea-level than during periods of high sea-level (DiesterHaass, 1975b and unpublished results). Off the northern Sahara lowered sea level coincides with a humid climate, whereas south of $20^{\circ} \mathrm{N}$ lowered sea level, and thus higher glauconite amounts, coincides with arid climate during late Quaternary. This observation is explained because the formation of typical shallow water particles occurs close to the shelf break during periods of lowered sea level and the downslope distance is considerably shortened.

Glauconite and relict particles occur in amounts less than $1 \%$ in Site 369 (except for Core 369A-13, Figure $21)$. Nevertheless, their presence or absence is important since they indicate variations in shallow water supply. From the observations in late Quaternary sediments and from the climatic results, it is assumed that during the early Miocene, sea level was considerably lower than in younger sections. Especially in the lower early Miocene, sea level was much lower as indicated by the presence of shallow water particles, such as glauconite (amounts up to 9\%), relict particles, dolomite rhombs, caecidae (shallow water gastropods), and the large amounts of quartz grains, partly dune sands. Berger and von Rad (1972) also found significant amounts of shallow water particles (quartz, fecal pellets, glauconite, phosphorite) in early Miocene sediments off northwest Africa at Sites 138, 139, and 140. This transport of shallow water particles indicates a lower sea level. The decreasing amounts of shallow water particles and dune sand from Cores 369A-12 to 369A-8 suggest an elevation of sea level.

This interpretation is in good agreement with results of Dillon and Sougy (1974) who describe an important regression for the upper Oligocene/lower early Miocene and with Templeton (1971) who mentions an early Miocene regression. An unconformity during this period (Pimm and Hayes, 1972) is attributed to shallow water erosion or subaerial denudation and a considerable Neogene subsidence by Hinz et al. (1974). According to Dillon and Sougy (1974), the sea level again rose from the middle early Miocene upwards. However, Reyre (1966) mentions a lower Miocene transgression. A post-Oligocene transgression is also described by Rona (1973). He mentions an increase in sedimentation rate in post-Oligocene times in a well near Cape Blanc and attributes this to a transgression.

It cannot be decided whether all the humid periods in the upper part of Site 369 can be related to low sea-level stands like those in the late Quaternary, but for the interval at Sections 369-4-5 to 369-5-4 a lowered sea level is presumed. Glauconite amounts are relatively high, up to $0.8 \%$ of the sand fraction. This layer has large amounts of terrigenous material and low desert quartz numbers and cold water temperatures (Pflaumann, this volume). Perhaps it corresponds to a humid period and lowered sea level due to glacier advance, as do the late Quaternary humid sections in this region. The interpretation of this layer, deposited during a period of lowered sea level, correlates again with observations of Dillon and Sougy (1974) who describe a major regression within the late Miocene.

The shallow water particles at Site 367 were brought to the site by turbidity currents (see Sarnthein, this volume). No conclusion as to sea-level can be drawn because of the discontinuous coring and the small number of samples. Site $366 \mathrm{~A}$ does not contain terrigenous components $>40 \mu \mathrm{m}$ in diameter or shallow water particles. Its position on the Sierra Leone Rise protects it from the bottom transport and so the site cannot give indications as to climate or sea level changes. For terrigenous components $<40 \mu \mathrm{m}$, see Futterer (this volume).

\section{Volcanism}

The origin of the volcanic glass and ash at Site 369 can perhaps be attributed to volcanic phases from the Canary Islands. The first appearance of volcanic material at Site 369 is in the middle Miocene at about 15 m.y.B.P. In the middle Miocene at about 12-13 m.y.B.P., the amount of volcanic material increases, decreasing in the lower late Miocene at about 9 m.y.B.P., and disappearing in the middle late Miocene at about 7-8 m.y.B.P. A small amount of volcanic material reappears in the uppermost late Miocene (about 5-6 m.y.B.P.). The ages given have been calculated assuming constant sedimentation rates and are based on the time scale of Berggren and van Couvering (1974). The distribution of volcanic material at Site 369 correlates well with potassium-argon age determinations of volcanic samples from the Canary Islands. Lietz and Schmincke (1975) found a volcanic phase on Gran Canaria from 14-9.6 m.y.B.P., which probably corresponds to the volcanic material found in Cores 369A-1 to 369A-7. The Pliocene volcanic phase described by Lietz and Schmincke (1975) is not reflected at Site 369 where Pliocene sediments are lacking.

Abdel-Monem et al. (1971, 1972) made potassiumargon age determinations on samples from all the Canary Islands. They found two major phases of volcanic activity; from about 16 to 5 m.y.B.P. and from 2 to 0.2 m.y.B.P. The Pleistocene volcanic phase is not reflected at Site 369. K-Ar age determinations described by Grunau et al. (1975) show that extrusives occurred on Fuerteventura and Gran Canaria (islands closest to Site 369 ) from 16.5 to 9 m.y.B.P. 
The volcanic material at Site 368 occurs in older sections between about 18 and 14 m.y.B.P. It is not known whether the volcanic glass and ash came from the Cape Verde Islands or from the Dakar region. Volcanic activity is known for both regions during the Miocene (Dillon and Sougy, 1975; Mitchell-Thomé, 1972). After Grunau et al. (1975), volcanic activity on the Cape Verde Island Maio began in the upper Oligocene and lasted until about 10 m.y.B.P. On the Cape Verde Islands no volcanic glass has been found (Mitchell-Thomé, 1972), whereas the sediments at Site 368 contain high amounts of glass.

Coarse fraction analysis results concerning carbonate dissolution, climate, sea level changes, and volcanism are summarized schematically in Figure 6.

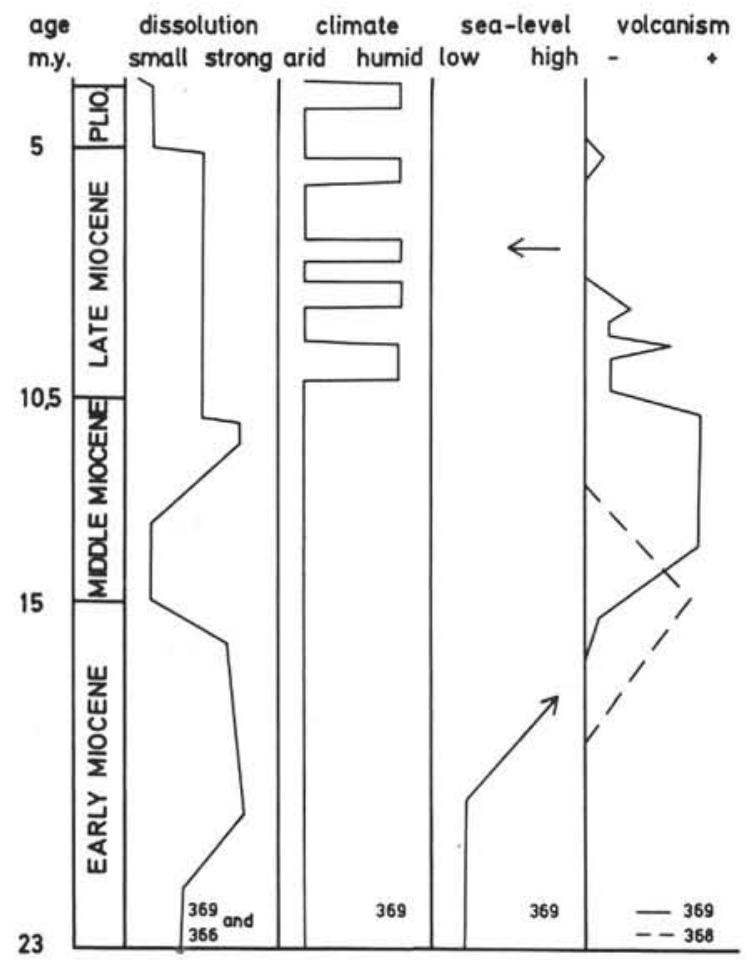

Figure 6. Diagram showing schematically results concerning carbonate dissolution, climate, sealevel changes, and volcanism. Left side: ages in million years after Berggren and van Couvering (1974).

\section{ACKNOWLEDGMENTS}

I thank the scientific crew of DSDP Leg 41 , expecially U. Pflaumann and E. Seibold for providing samples and discussions. The manuscript has been read by W. Berger, E. Seibold, and R. Wilson. I with to express my sincere thanks to W. Schnitzer, Würzburg, who provided working facilities. A. Rongitsch prezared samples and drawings. I thank the Deutsche Forschungsgemeinschaft for supporting this investigation.

\section{REFERENCES}

Abdel-Monem, A., Watkins, N.D., and Gast, P.W., 1971. Potassium-argon ages, volcanic stratigraphy, and geomagnetic polarity history of the Canary Islands: Lanzarote, Fuerteventura, Gran Canaria and La Gomera: Am. Jr. Sci., v. 271, p. 490-521.
1972. Potassium-argon ages, volcanic stratigraphy, and geomagnetic polarity history of the Canary Islands: Tenerife, LaPalma, and Hierro: Am. Jr. Sci., v. 272, p. 805-825.

Arrhenius, G., 1952. Sediment cores from the east Pacific: Rept. Swedish Deep-Sea Exped., v. 5, p. 1-227.

Bagnold, R.A., 1954. The physics of blown sand and desert dunes: London. (Methuen and Co. Ltd.).

Berger, W.H., 1968. Planktonic foraminifera: selective solution and paleoclimatic interpretation: Deep-Sea Res., v. 15 , p. $31-43$. 1970, Planktonic foraminifera: selective solution and the lysocline: Mar. Geol., v. 8, p. 111-138.

1971. Sedimentation of planktonic foraminifera: Mar. Geol., v. 11, p. 325-358.

1973. Deep-sea carbonates: Pleistocene dissolution cycles: Jr. Foram. Res., v. 3/4, p. 187-195.

1974. Deep-sea sedimentation. In Burk, C.A. and Drake, C.L. (Eds.), The geology of continental margifs: New York, Heidelberg, Berlin (Springer Verlag), p. 213241

Berger, W.H. and von Rad, U., 1972. Cretaceous and Cenozoic sediments from the Atlantic Ocean. In Hayes, D.E., Pimm, H.C., et al., Initial Reports of the Deep-Sea Drilling Project, Volume 14: Washington (U.S. Government Printing Office), p. 787-954.

Berger, W.H. and Winterer, E.L., 1974. Plate stratigraphy and the fluctuating carbonate line: Spec. Publ. Int. Assoc. Sediment., v. 1, p. 11-48.

Berggren, W.A. and van Couvering, J.A., 1974. The late Neogene: biostratigraphy, geochronology and paleoclimatology of the last 15 million years in marine and continental sequences: Paleogeogr., Paleoclimatol., Paleoecol., v. 16, p. 1-216.

Cita, M.B., 1971. Biostratigraphy, chronostratigraphy and paleoenvironment of the Pliocene of the Cape Verde (North Atlantic): Rev. Micropal., v. 14, p. 17-42.

Cornelius, C.D., 1971. Die Drifttheorie im Lichte der Sahara Geologie. In Schiffers, H. (Ed.), Die Sahara und ihre Randgebiete: Bd. 1, Munchen (Weltforum Verlag), p. 156188.

Diester-Haass, L., 1975a. Influence of deep-oceanic currents on calcareous sands off Brazil. IXieme Congrès International de Sédimentologie, Nice, 1975. Publications du Congrês, v. 8, p. 25-30.

1975b. Sedimentation and climate in the late Quaternary between Senegal and the Cape Verde Islands: Meteor Forsch. Ergebn., v. 20, p. 1-32.

1976a. Late Quaternary climatic variations in NW Africa deduced from East Atlantic sediment cores: Quat. Res., v. 6, p. 299-314.

1976b. Quaternary accumulation rates of biogenous and terrigenous components on the East Atlantic continental slope off NW Africa: Mar. Geol., v. 21, p. 1-24.

in press. Sediments as indicators of upwelling. Proc., of the Third Internat. Symp. Upwetling Ecosystems, Proc., Kiel, 1975. New York, Heidelberg, Berlin (Springer Verlag).

Diester-Haass, L., Schrader, H.-J., and Thiede, J., 1973. Sedimentological and paleoclimatological investigations of two pelagic ooze cores off Cape Barbas, Northwest Africa. Meteor Forsch. Ergebn., v. 16, p. 19-66.

Dillon, W.P. and Sougy, J.M.A., 1974. Geology of West Africa and Canary and Cape Verde Islands. In Nairn, E.M. and Stehli, F.C. (Eds.), The ocean basins and margins, v. 2, The North Atlantic: New York, London (Plenum Press), p. 315-390.

Elouard, P., 1959. Etude géologique et hydrogéologique des formations sédimentaires du Guebla mauritanien et de la 
vallée du Sénégal. Thèse Science Paris. Mém. Bur. Rech. Geol. Min. Paris.

Grunau, H.R., Lehner, P., Cleintuar, M. R., Allenbach, P., and Bakker, G., 1975. New radiometric ages and seismic data from Fuerteventura (Canary Islands), Maio (Cape Verde Islands), and Sao Tomé (Gulf of Guinea): "Progress in Geodynamics" Royal Netherlands Acad. Arts and Science, Amsterdam.

Hinz, K., Seibold, E., and Wissmann, G., 1974. Continental slope anticline and unconformities off West Africa: Meteor Forsch. Ergebn., v. 17, p. 67-73.

Kudrass, H.-R., 1973. Sedimentation am Kontinentalhand vor Portugal und Marokko im Spatpleistozan and Holozan. Meteor Forsch. Ergebn., v. 13, p. 1-63.

Lietz, J. and Schmincke, H.U., 1975. Miocene-Pliocene sea level changes and volcanic phases on Gran Canaria (Canary Islands) in the light of new $\mathrm{K}-\mathrm{Ar}$ ages: Paleogeogr., Paleoclimat., Paleoecol., v. 18, p. 213-239.

Michel, P., 1973. Les bassins des fleuves Sénégal et Gambie. Etude géomorphologique: Mém. ORSTROM, no. 63, Paris.

Mitchell-Thomé, R.C., 1972. Outline of the geology of the Cape Verde Archipelago: Geol. Rdsch., v. 61, p. 10871109.

Monod, T., 1963. The Late Tertiary and Pleistocene in the Sahara and adjacent southerly regions. In Howell, F.C. and Bourlière, F. (Eds.), Viking Fund. Publ. Anthropology, v. 36: African ecology and human evolution, p. 117-229.

Norris, R.M., 1969. Dune reddening and time: J. Sediment. Petrol., v. 39, p. 7-11.

Pimm, A.C. and Hayes, D.E., 1972. General synthesis. In Hayes, D.E., and Pimm, A.C., et al. Initial Reports of the Deep Sea Drilling Project, Volume 14. Washington (U.S. Government Printing Office), p. 955-975.

Radcewski, O.E., 1937. Die Mineralfazies der Sedimente des Kapverden Beckens: Wiss. Ergebn. Dt. Atlant. Exped. Meteoŕ 1925-1927, Bd. III, v. 3, p. 262-277.

Ramsay, A.T.S., 1974. The distribution of calcium carbonate in deep-sea sediments. In Hay, W.W. (Ed.), Studies in Paleooceanography: Soc. Econ. Pal. Min., Spec. Publ., v. 20 , p. $58-76$.

Reyre, D., 1966. Particularities géologiques des bassins cotiers de l'ouest africain. In Sedimentary basins of the
African Coasts: Assoc. African. Geol. Survey, Paris, p. 253-273.

Riedel, W.R., 1959. Siliceous organic remains in pelagic sediments. In Silica in Sediments: Soc. Econ. Pal. Min., Spec. Pub., v. 7, p. 80-91.

Rona, P.A., 1973. Relations between rates of sediment accumulation on continental shelves, sea-floor spreading, and eustacy inferred from the central North Atlantic: Geol. Soc. Am. Bull., v. 84, p. 2851-2872.

Sarnthein, M., 1971. Oberflächensedimente im Persischen Golf und Golf von Oman. II. Quantitative Komponentenanalyse der Grobfraktion. Meteor Forsch. Ergebn., v. 5, p. 1-113.

Sarnthein, M. and Diester-Haass, L., 1976. Eolian sand turbidites: J. Sediment. Petrol.

Savin, M.S., Douglas, R.G., and Stehli, F.G., 1975. Tertiary marine paleotemperatures: Geol. Soc. Am. Bull., v. 86, p. $1499-1510$.

Schwarzbach, M., 1954. Das Alter der Wuste Sahara: N. Jb. Geol. Pal. Mh. Jg. 1953, p. 157-174.

Tastet, J.P., 1971. Le contexte géologique du site d'Abidjan. Ann. Univ. Abidjan, Sér. G, v. 3, p. 225-246.

Templeton, R.S.M., 1971. The geology of the continental margin between Dakar and Cape Palmas. ICSU/SCOR Working Party 31, Symp. Cambridge, 1970. Inst. Geol. Sci. Rept. No. 70/16, p. 43-60.

Tessier, F., Flicoteaux, R., Lappartient, J.-R., Nahon, D. and Triat, J.M., 1975. Reform of the concept of "Continental Terminal" in the coastal sedimentary basins of West Africa: Trav. Lab. Sci. Terre, St. Jérome, Marseille, (A), no. 8.

Tooms, J.S., Summerhayes, C.P., and McMaster, R.L., 1971. Marine geological studies on the north-west African margin: Rabat-Dakar. ICSU/SCOR Working Party 31, Symp. Cambridge, 1970. Inst. Geol. Sci. Rept. No. 70/16, p. 9-25.

van Andel, T.H., 1975. Mesozoic/Cenozoic calcite compensation depth and the global distribution of calcareous sediments: Earth Planet. Sce. Lett., v. 26, p. 187-194.

Walker, T.R., 1967. Formation of red beds in modern and ancient deserts: Geol. Soc. Am. Bull., v. 78, p. 353-368. 